Article

\title{
Evolution of Aerosols in the Atmospheric Boundary Layer and Elevated Layers during a Severe, Persistent Haze Episode in a Central China Megacity
}

\author{
Yunfei Zhang ${ }^{1,2,3, *}$, Yunpeng Zhang ${ }^{1,2,3}$, Changming $\mathrm{Yu}^{1,2,3}$ and Fan $\mathrm{Yi}^{1,2,3}$ \\ 1 School of Electronic Information, Wuhan University, Wuhan 430072, China; zyp@whu.edu.cn (Y.Z.); \\ ycm@whu.edu.cn (C.Y.); yf@whu.edu.cn (F.Y.) \\ 2 Key Laboratory of Geospace Environment and Geodesy, Ministry of Education, Wuhan 430072, China \\ 3 State Observatory for Atmospheric Remote Sensing, Wuhan 430072, China \\ * Correspondence: zhangyunf@whu.edu.cn
}

check for updates

Citation: Zhang, Y.; Zhang, Y.; Yu, C.; Yi, F. Evolution of Aerosols in the Atmospheric Boundary Layer and Elevated Layers during a Severe, Persistent Haze Episode in a Central China Megacity. Atmosphere 2021, 12, 152. https://doi.org/10.3390/atmos 12020152

Academic Editor: Klaus Schäfer Received: 19 November 2020

Accepted: 20 January 2021

Published: 25 January 2021

Publisher's Note: MDPI stays neutral with regard to jurisdictional claims in published maps and institutional affiliations.

Copyright: (c) 2021 by the authors. Licensee MDPI, Basel, Switzerland. This article is an open access article distributed under the terms and conditions of the Creative Commons Attribution (CC BY) license (https:/ / creativecommons.org/licenses/by/ $4.0 /)$.

\begin{abstract}
Aerosol vertical profiling is crucial to understand the formation mechanism and evolution processes of haze, which have not yet been comprehensively clarified. In this study, we investigated a severe, persistent haze event in Wuhan $\left(30.5^{\circ} \mathrm{N}, 114.4^{\circ} \mathrm{E}\right)$, China during 5-18 January 2013 by the use of a polarization lidar, a Cimel sun photometer, meteorological datasets, and the hybrid single-particle Lagrangian integrated trajectory (HYSPLIT) model, focusing on the time-height evolution of aerosols in both the atmospheric boundary layer (ABL) and elevated layers. During the haze period, the integrated particle depolarization ratio was $0.05 \pm 0.02$, and the fine mode fraction reached $0.91 \pm 0.03$, indicating haze particles were rather spherical and predominately submicron, that is, of anthropogenic nature. Compared with the clear period, columnar aerosol optical depth at $500 \mathrm{~nm}$ tripled to $1.32 \pm 0.31$, and the strongest enhancement in aerosol concentration occurred from near the ground to an altitude of $1.2 \mathrm{~km}$ during the haze period. The daytime evolution of aerosol vertical distribution in the ABL exhibited a distinct pattern under haze weather. Abundant particles accumulated below $0.5 \mathrm{~km}$ in the morning hours due to stable meteorological conditions, including a strong surface-based inversion $\left(4.4-8.1^{\circ} \mathrm{C}\right)$, late development (from 1000-1100 LT) of the convective boundary layer, and weak wind $\left(<4 \mathrm{~m} \cdot \mathrm{s}^{-1}\right)$ in the lowermost troposphere. In the afternoon, improved ventilation delivered an overall reduction in boundary layer aerosols but was insufficient to eliminate haze. Particularly, the morning residual layer had an optical depth of 0.29-0.56. It influenced air quality indirectly by weakening convective activities in the morning and directly through the fumigation process around noon, suggesting it may be an important element in aerosol-ABL interactions during consecutive days with haze. Our lidar also captured the presence of the elevated aerosol layers (EALs) embodying regional/long-range transport. Most of the EALs were observed to subside to $<1.2 \mathrm{~km}$ and exacerbate the pollution level. Backward trajectory analysis and lidar data revealed the EALs originated from the transport of anthropogenic pollutants from the Sichuan Basin, China, and of dust from the deserts in the northwest. They were estimated to contribute $\sim 19 \%$ of columnar aerosol-loading, pointing to a non-negligible role of transport during the intense pollution episode. The results could benefit the complete understanding of aerosol-ABL interactions under haze weather and air quality forecasting and control in Wuhan.
\end{abstract}

Keywords: haze; lidar; atmospheric boundary layer; elevated aerosol layer

\section{Introduction}

In recent decades, rapid urbanization, frequent industrial activities, and population expansion have produced high levels of anthropogenic emissions over central and eastern China. Consequently, the occurrence of haze shows a rapid increase in these regions [1], where the average number of annual hazy days exceeded 35 in 2011. From 2010, China implemented active regulations such as the Clean Air Action to fight against air pollution, 
and various anthropogenic emissions have been reduced since then [2]. However, haze episodes still occur frequently over central and eastern China (e.g., [3,4]). The reason for the contradiction may rest on the complexity of the formation mechanism and evolution processes of haze [5-7], which has not yet been fully understood [8]. Haze can exert noticeable effects on regional climate, including hydrological cycle [9] and air temperature variations [10]. Moreover, haze pollutants such as fine particulate matter $\left(\mathrm{PM}_{2.5}\right)$ contain multiple toxic compounds and can be easily inhaled into the lungs, causing damage to human respiratory and cardiovascular systems [11,12]. To resolve the problem of air pollution as well as its impacts on regional climate, it is crucial to fully understand the formation and evolution of haze pollution.

Many studies have been performed to examine the above-mentioned aspects of haze over central and eastern China. Adverse meteorological conditions in the atmospheric boundary layer (ABL) and regional/long-range transport are well documented as two major factors that manipulate the formation and evolution of haze events. The increase of surface aerosol concentration is closely related to stagnant boundary-layer meteorological conditions such as temperature inversion [13], shallow ABL [14,15], and weakened surface wind [16]. In-depth studies revealed pronounced interactions between aerosols and the ABL [17-19], which could have a significant influence on air quality [20]. Abundant aerosols under haze weather can greatly reduce surface heat flux [17] but cause substantial heating in upper ABL [19]. Both effects further stabilize the ABL and thus worsen air quality or prolong the haze event [18]. Up to now, our understandings of aerosol-ABL interactions are still very limited [21]. A key question lies in how aerosol vertical distribution evolves with the development of the ABL [20]. Vertical distribution of multiple pollutants and turbulent flux can be continuously collected by the meteorological tower [18], while the detecting range $(\sim 300 \mathrm{~m})$ of this instrument is too short to cover the whole ABL. In situ aircraft measurements could capture different types of aerosol vertical distribution related to the ABL structure [22], but they are only available in the field campaigns, and the number of samples is very limited. Light detection and ranging (lidar), yielding vertical profiling of aerosol optical properties with high temporal (from seconds to minutes) and vertical resolution (from meters to tens of meters), has been used to obtain timely boundary layer height and its development $[23,24]$. Continuous lidar observations, therefore, provide the opportunity to gain further insights into aerosol-ABL interactions under haze weather.

Transport could also be an important contributor to the pollution level. For example, Wang et al. [25] simulated air quality in the North China Plain in January 2013 using the nested air quality prediction model system and found the contribution of regional transport to the $\mathrm{PM}_{2.5}$ concentration can be larger than that of local emissions. Qin et al. [26] monitored a sustained decrease in visibility caused by the importing of aerosol plumes during a large-scale haze event. These studies have yielded plentiful knowledge, but great controversies exist about the significance of transport in haze pollution [27-29], due partly to a shortage of direct observations of regional/long-range transport under haze weather. Lidar can readily capture the time-height evolution of transported plumes such as Asian dust [30], Californian smoke [31], and Eyjafjallajokull volcanic ash [32] in the free troposphere. Combining lidar data with backward trajectory analysis, direct observations of transported aerosol layers regarding their intensity, vertical extent, and origins can be carried out. All the information could enhance our understanding of haze formation and evolution.

Wuhan $\left(30.5^{\circ} \mathrm{N}, 114.4^{\circ} \mathrm{E}\right)$, a highly industrialized megacity with $>10$ million residents, has been experiencing severe haze pollution in recent years [33]. Nevertheless, comprehensive studies of haze weather in Wuhan are rare [34]. Aiming at further understanding of the formation mechanism and evolution processes of haze, we characterize a severe, persistent haze episode in Wuhan in January 2013 with a polarization lidar, a Cimel sun photometer, meteorological datasets, and a backward trajectory model. In this study, considerable attention is paid to the interpretation of aerosol-ABL interactions via aerosol 
vertical profiling during the haze period. We also emphasize the process-level depiction of how transported aerosol plumes affect local pollution levels.

\section{Instruments and Data}

The observation site $\left(30.5^{\circ} \mathrm{N}, 114.4^{\circ} \mathrm{E}, 70 \mathrm{~m}\right.$ above sea level) is located in the urban area of Wuhan city. Wuhan city is situated in the Jianghan Plain in central China and has a subtropical monsoon climate with four distinctive seasons.

\subsection{Polarization Lidar}

We built a zenith-angle scanning polarization lidar at our observation site in August 2012, aiming to promote the studies of aerosol typing and cloud phase discrimination in Wuhan. A frequency-doubled Neodymium-doped Yttrium Aluminum Garnet (Nd:YAG) laser was employed as the lidar transmitter, producing pulses of $\sim 60 \mathrm{~mJ}$ at $532 \mathrm{~nm}$ with a repetition of $20 \mathrm{~Hz}$. The laser pulses then pass through a Brewster polarizer to improve the polarization purity (up to 10,000:1). After beam expansion, the outgoing beam with a divergence of $0.2 \mathrm{mrad}$ was transmitted into the atmosphere. The polarized components of elastically backscattered signals in parallel and perpendicular directions were collectively received by a $200 \mathrm{~mm}$ diameter Cassegrain telescope. Subsequently, the backscattered signals were separated using a polarization beam splitter prism (PBS). To reduce the crosstalk between the two polarization channels, one polarizer was installed on each output of the PBS. At last, the light signals were focused onto the photomultiplier tubes (PMTs) and recorded by a PC-controlled two-channel transient digitizer (TR40-160, manufactured by Licel GmbH, Berlin, Germany). The TR40-160 makes simultaneous analog and photon counting acquisition for each channel. Either type of acquisition may suffer from signal saturation in the lowermost troposphere or low signal-to-noise ratio at high altitudes. Gluing was a methodology $[35,36]$ to made full use of both photon counting and analog signals to improve the dynamic range of lidar measurements. After gluing, we could obtain lidar profiles with complete altitude coverage and improved dynamic range (up to $10^{5}$ ). The glued data had a time resolution of $1 \mathrm{~min}$ and a range resolution of $3.75 \mathrm{~m}$.

Both the transmitting and receiving units of the lidar system were fixed on an optical bench, which was rotatable under the control of an electric motor. The zenith angle of the lidar system was adjustable in the range from 0 to $70^{\circ}$. The zenith angle of the lidar system, which was $29^{\circ}$ during the entire period, was determined by comparison of backscattering signals in the presence of aerosol layers to a reference $532 \mathrm{~nm}$ polarization lidar [24,37] at our observation site. To reduce the blind area of the lidar system, the telescope was mounted in a compact way that minimizes its distance from the optical axis of the outgoing beam. Accordingly, the full overlap between the laser beam and the receiver field of view was achieved at $0.2 \mathrm{~km}$ above the ground. The detection of the nocturnal boundary layer was impossible. The specifications of the polarization lidar system are given in Table 1.

Table 1. Specifications of the polarization lidar at our observation site $\left(30.5^{\circ} \mathrm{N}, 114.4^{\circ} \mathrm{E}\right)$ in Wuhan, China.

\begin{tabular}{cc}
\hline Parameter & Specification \\
\hline & Transmitter \\
\hline Laser model & Continuum Inlite II-20 \\
Wavelength & $532 \mathrm{~nm}$ \\
Energy per pulse & $\sim 60 \mathrm{~mJ}$ \\
Pulse repetition rate & $20 \mathrm{~Hz}$ \\
Pulse width & $5-7 \mathrm{~ns}$ \\
Beam divergence & $\sim 0.2 \mathrm{mrad}$ \\
\hline
\end{tabular}


Table 1. Cont.

\begin{tabular}{cc}
\hline Parameter & Specification \\
\hline & Receiver \\
\hline Telescope & Cassegrain \\
Primary mirror diameter & $200 \mathrm{~mm}$ \\
Field of view & $1.0 \mathrm{mrad}$ \\
PBS & $\mathrm{T}_{\mathrm{p}}>95 \%, \mathrm{R}_{\mathrm{s}}>99 \%$ \\
Filter bandwidth & $0.3 \mathrm{~nm}$ \\
PMT & Hamamatsu H10721 \\
\hline Acquisition model & Other \\
Positioning & Licel TR40-160 \\
\hline
\end{tabular}

Range-resolved profiles of aerosol extinction coefficient $\left(\alpha_{a}\right)$ were determined with backward integration scheme of the iteration method proposed by Fernald and Klett [38,39] as:

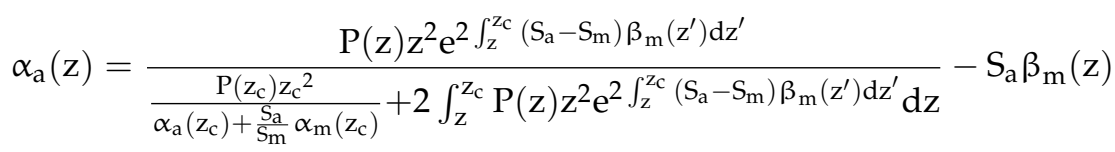

where $\mathrm{P}(\mathrm{z})$ represents Mie backscattering signal, $\mathrm{z}_{\mathrm{c}}$ is the reference height, $\beta_{\mathrm{m}}, \alpha_{\mathrm{m}}$, and $\mathrm{S}_{\mathrm{m}}$ denote molecular backscattering and extinction coefficients and extinction-to-backscattering ratio ( $8 \pi / 3$ for earth atmosphere) respectively, and $S_{a}$ is the aerosol extinction-to-backscattering ratio, i.e., the lidar ratio. $\beta_{\mathrm{m}}$ profiles were computed from radiosonde observations closest in time. Radiosonde observations were conducted twice a day at 0000 UTC (0800 LT) and 1200 UTC (2000 LT) by the Wuhan Weather Station $\left(30.6^{\circ} \mathrm{N}, 114.1^{\circ} \mathrm{E}\right)$, which is $\sim 23 \mathrm{~km}$ away from our lidar site. Based on previous characterizations of urban/industrial aerosols [40,41], a fixed $S_{a}$ of 57 sr was used in our retrieval. With the matching method (e.g., [42]), $z_{c}$ was determined at between $12-15 \mathrm{~km}$, where aerosol content could be zero. To evaluate aerosol content in the upper troposphere of Wuhan, we explore Lidar Level 3 Tropospheric Aerosol Data Product version 4.20 [43] from the space-borne polarization lidar on board the Cloud-Aerosol Lidar and Infrared Pathfinder Satellite Observation (CALIPSO). The globally gridded aerosol dataset has a spatial resolution of $2^{\circ}$ (latitude) $\times 5^{\circ}$ (longitude) and reports monthly average cloud-free profiles of $\alpha_{a}$ at $-0.4-12.1 \mathrm{~km}$ at $532 \mathrm{~nm}$ (the same wavelength as our polarization lidar). Figure 1 presents the monthly average $\alpha_{a}$ profile for the nearest spatial grid (central point: $30.0^{\circ} \mathrm{N}, 112.5^{\circ} \mathrm{E}$ ) in January 2013. The results showed an aerosol-free region at the altitudes of 9-12.1 km. We thus assume $\alpha_{\mathrm{a}}$ equals $0.0 \mathrm{at} \mathrm{z}_{\mathrm{c}}$ in the retrievals. Lower reference heights were chosen on the occurrence of clouds, and the boundary condition was determined according to adjacent cloud-free profiles. It is worth noting that $\alpha_{a}$ retrievals rapidly lose their dependence on the initial guess of the backscattering parameters at the reference height under haze weather. As mentioned by Bitar et al. [44], the uncertainty in $\alpha_{a}$ was induced by the noise in $P(z)$, selection of $S_{a}$, and uncertainties concerning the boundary condition [44]. The detailed error analysis was given by Comerón et al. [45] and Zhuang and Yi [37]. In our retrievals, the time and range resolutions of the lidar data were degraded to $5 \mathrm{~min}$ and $30 \mathrm{~m}$, respectively, to reduce the noise in $\mathrm{P}(\mathrm{z})$. Finally, the overall uncertainty in $\alpha_{\mathrm{a}}$ was estimated to be $15-20 \%$ if we assume an uncertainty of $10 \%$ in $S_{a}$ and $0.0075 \mathrm{~km}^{-1}$ (for cloud-free profiles) or $15 \%$ (on the occurrence of cloud) in $\alpha_{a}$ at the reference heights.

Since the perpendicular- and parallel-polarized channels of the lidar system had different responses, the gain ratio between the two channels needed to be determined to obtain the volume depolarization ratio. The gain ratio was determined by using the $\pm 45^{\circ}$ method proposed by Freudenthaler et al. [46], which was 0.071 for our lidar system during 
the observation period. The volume depolarization ratio $\left(\delta_{\mathrm{v}}\right)$ was obtained based on the following expression [47]:

$$
\delta_{\mathrm{v}}=\mathrm{k} \frac{\mathrm{P}_{\perp}}{\mathrm{P}_{/ /}}
$$

where $\mathrm{P}_{/ /}$and $\mathrm{P}_{\perp}$ represent the backscattering signals of the parallel- and perpendicularpolarized channels, respectively, and $\mathrm{k}$ denotes the gain ratio. The particle depolarization ratio $\left(\delta_{a}\right)$ could be then derived according to the following equation:

$$
\delta_{\mathrm{a}}=\frac{\delta_{\mathrm{v}}\left(\mathrm{R}+\mathrm{R} \delta_{\mathrm{m}}-\delta_{\mathrm{m}}\right)-\delta_{\mathrm{m}}}{\mathrm{R}-1+\mathrm{R} \delta_{\mathrm{m}}-\delta_{\mathrm{v}}}
$$

where $\mathrm{R}$ is the aerosol backscatter ratio, and $\delta_{\mathrm{m}}$ is the molecular depolarization ratio, which is 0.004 for our lidar system based on the calculation described by Behrendt and Nakamura [48]. $\delta_{a}$ strongly depends on the morphology of aerosols since non-spherical particles would create depolarization into the Mie backscattering signals [47]. The pure dust particles could have $\delta_{a}$ values of $0.28-0.35$ [41,49], while $\delta_{a}$ is close to zero for liquid aerosol droplets [50]. Typical values of 0.03-0.06 were measured for worldwide anthropogenic aerosols $[41,51,52]$.

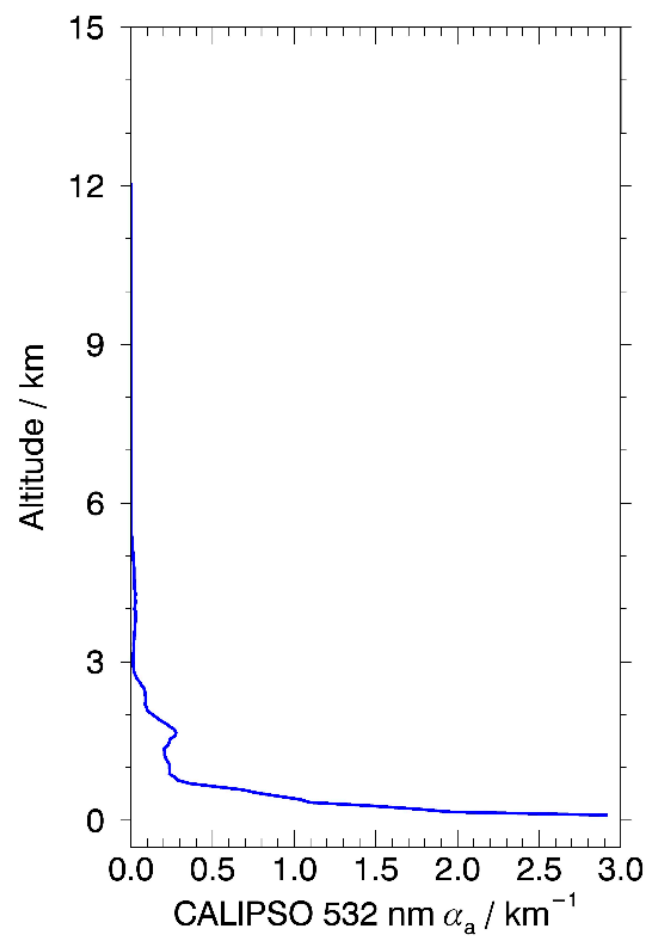

Figure 1. Monthly average profile of $532 \mathrm{~nm} \alpha_{a}$ in January 2013 for the spatial grid (central point: $30.0^{\circ} \mathrm{N}, 112.5^{\circ} \mathrm{E}$ ) from the Cloud-Aerosol Lidar and Infrared Pathfinder Satellite Observation (CALIPSO) Lidar Level 3 Tropospheric Aerosol Data Product version 4.20. An aerosol-free region (at the altitudes of 9-12.1 km) is identified.

\subsection{Sun Photometer}

A sun-sky scanning spectral photometer (CE318N-EBM9, manufactured by Cimel Electronique, Paris, France) was installed on the roof of the building at our observation site in April 2008 and has been in continuous operation since then. It measures direct solar irradiance at 340, 380, 440,500, 675, 870, 936, 1020, and $1246 \mathrm{~nm}$ every $15 \mathrm{~min}$. These solar measurements were applied to calculate the aerosol optical depth (AOD or $\tau_{\mathrm{a}}$ ) at each wavelength by using the Beer-Lambert law except for the $936 \mathrm{~nm}$ channel, where strong water vapor absorption exists. 
Routine calibration of the direct solar channels of our photometer was performed every 6-12 months by the use of the Langley plot technique [53]. The AOD uncertainty due to calibration was $\sim 0.015$ at $440-1020 \mathrm{~nm}$ and $\sim 0.035$ for the 340-380 nm channel under the optical air mass of 1.0. These values were slightly higher than or of the order of the total uncertainty (0.01-0.02) in AOD from the Aerosol Robotic Network (AERONET) field instruments [54]. Note that the total uncertainty in the AOD measurements from Cimel sun photometry was due primarily to the calibration [55]. AOD uncertainty due to calibration, according to the Beer-Lambert law, shrinks under higher solar elevation angles. A cloud screening procedure [56] was adopted to eliminate cloud contamination in the data. Only calibrated and cloud-screened AODs were used in this study.

Following the spectral deconvolution algorithm [57,58], we retrieved columnar fine $\left(\tau_{\mathrm{a} 500 \mathrm{f}}\right)$ and coarse mode $\left(\tau_{\mathrm{a} 500 \mathrm{c}}\right)$ AOD as well as the fine mode fraction (FMF) of AOD at $500 \mathrm{~nm}$. The spectral AODs used as input to the algorithm were limited to the six Cimel wavelengths ranging from 380 to $1020 \mathrm{~nm}$.

\subsection{Meteorological Datasets}

The Global Surface Summary of the Day (GSOD) dataset (https:/ /www.ncei.noaa. gov/access/search/data-search/global-summary-of-the-day) is regularly compiled by the National Oceanic and Atmospheric Administration (NOAA)'s National Centers for Environmental Information (NCEI) and archives up to 18 surface meteorological variables from over 9000 stations located around the world [59]. Surface meteorological variables, including pressure, visibility, temperature, dew point, and wind speed, are provided as daily averages after extensive quality control. Weather indicator, a six-digit binary number that indicates whether rain, snow, hail, fog, thunder, or tornado/funnel cloud occurs during the day, is also archived. Based on the values of the visibility, calculated relative humidity $(\mathrm{RH})$, and weather indicator for each record, we classify the weather as clear, haze, fog, or precipitation. The weather was considered as "precipitation" if rain, snow, or hail was reported. A clear day was defined when the visibility was greater than $10 \mathrm{~km}$ (e.g., [60]). The non-precipitation weather with visibility lower than $10 \mathrm{~km}$ could be caused by the occurrence of haze or fog. The difference between the criteria of haze and fog resided mainly in the humidity level. Here, we defined the low-visibility weather with RH no more than $80 \%$ as haze (e.g., [61]) and higher RH as fog, respectively.

The GSOD data from 268 stations over central and eastern China $\left(100-125^{\circ} \mathrm{E}, 22.5-45^{\circ} \mathrm{N}\right)$ were used in this study. Figure 2 shows the locations of the GSOD stations and our observation site. Wuhan GSOD station was $\sim 31 \mathrm{~km}$ away from our observation site.
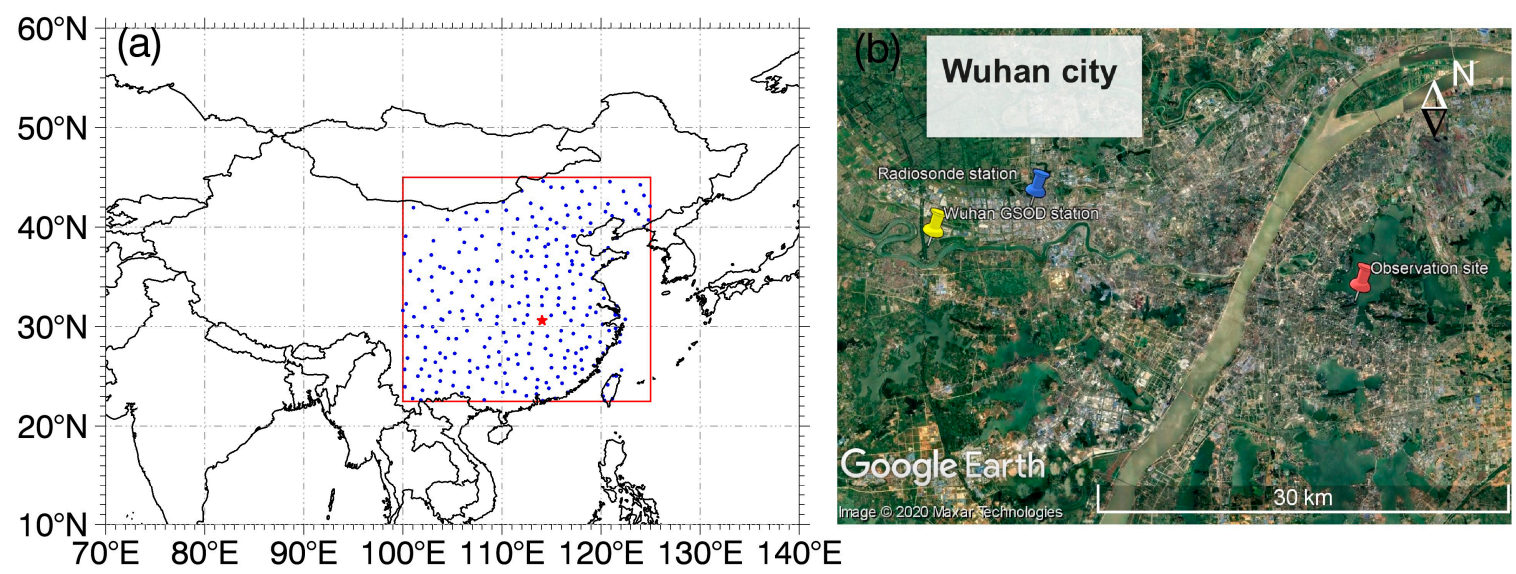

Figure 2. (a) Locations of the 268 GSOD stations (blue dots) over central and eastern China (100-125 E, 22.5-45 $\mathrm{N})$ and Wuhan city (red asterisk). (b) Locations of our observation site (red pin), GSOD station (yellow pin), and radiosonde station (blue pin) in Wuhan city. The image in panel (b) is reproduced with permission from Google Inc., 2020. 
Radiosonde observations deliver vertical profiles of pressure, temperature, relative humidity, and wind from the surface up to a height of $\sim 30 \mathrm{~km}$ twice a day. They could provide many atmospheric thermodynamic characteristics/processes, such as temperature inversion in the upper air of Wuhan.

We used the ERA5 reanalysis [62] to examine the ventilation conditions over central and eastern China. The ventilation coefficient $\left(\mathrm{V}_{\mathrm{c}}\right)$, defined by the product of atmospheric boundary layer height and surface wind speed [63], is a significant parameter in determining pollution potential over a region of interest since it indicates the ability of the atmospheric boundary layer to diffuse pollutants in both the horizontal and vertical directions [64]. In this study, two variables from ERA5 reanalysis, i.e., the boundary layer height and $10 \mathrm{~m}$ wind speed, were multiplied to construct the ventilation coefficient over central and eastern China following Rigby et al. [65]. ERA5 applies the Integrated Forecast System (IFS) cycle 41r2 of the European Center for Medium-Range Weather Forecasts (ECMWF) with 4-dimensional variational analysis. It provided hourly estimates of the atmosphere on a $0.25^{\circ} \times 0.25^{\circ}$ horizontal grid. As of May 2020, the first segment of the ERA5 reanalysis dataset was available from 1979 to the near present.

\subsection{Backward Trajectories}

The HYbrid Single-Particle Lagrangian Integrated Trajectory (HYSPLIT) model [66] is developed by NOAA's Air Resources Laboratory (ARL). HYSPLIT employs a hybrid between the Lagrangian approach and the Eulerian methodology in the calculation. It has been extensively used to simulate the transport and dispersion of atmospheric pollutants (e.g., [67]). In this study, the $72 \mathrm{~h}$ backward trajectories were calculated by using HYSPLIT version 4 to investigate the origins and transport pathways corresponding to the lidardetected elevated aerosol layers. The source location was set at our observation site $\left(30.5^{\circ} \mathrm{N}\right.$, $\left.114.4^{\circ} \mathrm{E}\right)$. For each trajectory, the ending time and altitude were chosen by inspection of lidar $\alpha_{\mathrm{a}}$ profiles. Meteorological fields used to drive the model were generated from the global data assimilation system (GDAS), and they had global coverage with a spatial resolution of $1^{\circ}$ and temporal resolution of $3 \mathrm{~h}$. HYSPLIT could be run interactively on the web release (https:/ / ready.arl.noaa.gov/hypub-bin/trajasrc.pl) with no restrictions in the computation of backward trajectories. In practice, the web release of the model was applied with "GDAS (1 degree, global, 2006-present)" being selected in the "Meteorology" menu.

\section{Results}

\subsection{Meteorological Background}

Figure 3 shows the time series of the daily average of surface temperature, pressure, relative humidity, wind speed, visibility, and $\mathrm{PM}_{2.5}$ mass concentration from 30 December 2012 to 20 January 2013 in Wuhan. The PM 2.5 mass concentration data were from the Wuhan Ecological Environment Bureau, and the other meteorological parameters were all obtained from the GSOD dataset. As seen from Figure 3c, the visibility was between 12 and $14 \mathrm{~km}$, and the mass concentration of $\mathrm{PM}_{2.5}$ was less than $80 \mu \mathrm{g} \cdot \mathrm{m}^{-3}$ from 30 December 2012 to 1 January 2013. These three days were characterized as one clear period. The $\mathrm{PM}_{2.5}$ mass concentration increased gradually from 3 January 2013, accompanied by a sustained degradation in the visibility. Accordingly, Wuhan witnessed the buildup and development of one haze episode during 5-8 January. The pollution level reached its summit on 10-12 January, when the $\mathrm{PM}_{2.5}$ mass concentration was between 270 and $310 \mu \mathrm{g} \cdot \mathrm{m}^{-3}$, and the visibility was less than $4 \mathrm{~km}$. Severe haze continued to linger over Wuhan in the following days until the precipitation during 19-20 January ended the haze event. Throughout the 14-day-long haze period, the relative humidity was between 50 and $75 \%$, and wind speed was mostly lower than $2 \mathrm{~m} \cdot \mathrm{s}^{-1}$ (Figure $3 \mathrm{~b}$ ). 


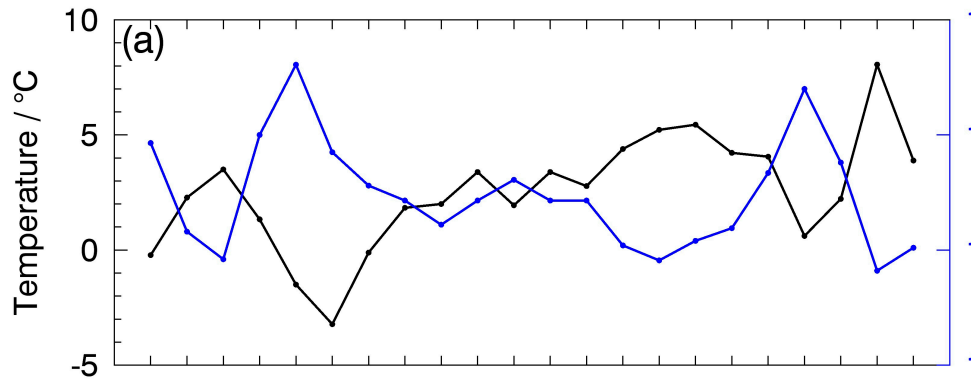

1040
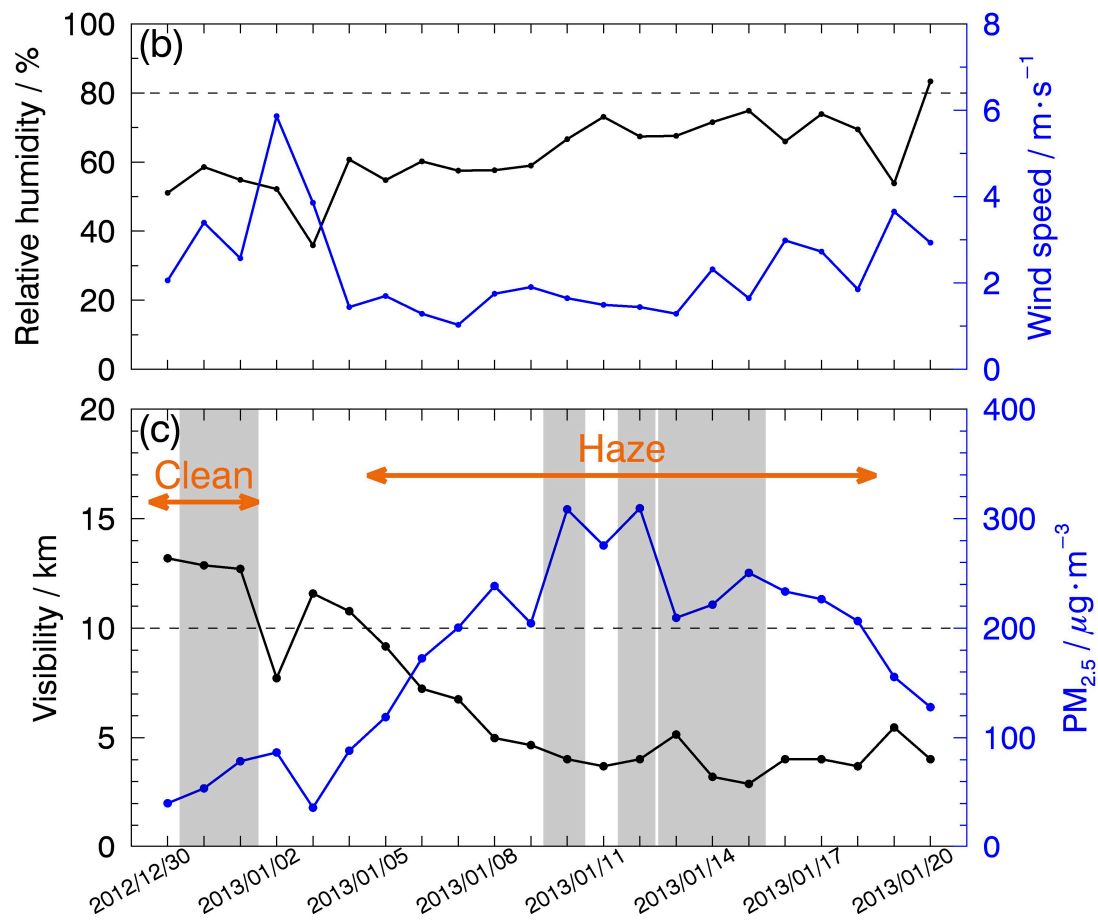

Figure 3. Daily average of surface (a) temperature and pressure, (b) relative humidity and wind speed, and (c) visibility and $\mathrm{PM}_{2.5}$ mass concentration from 30 December 2012 to 20 January 2013 in Wuhan. The horizontal dashed lines in panel $(\mathbf{b}, \mathbf{c})$ indicate relative humidity and visibility, which are equal to $80 \%$ and $10 \mathrm{~km}$, respectively. The clear and haze period are marked in panel (c) for further discussions. The shades in panel (c) indicate the intervals when lidar observations are available.

\subsection{Vertical Extent, Optical and Microphysical Properties of Haze Particles}

In total, 624 and 1491 profiles ( $5 \mathrm{~min} / 30 \mathrm{~m}$ resolution) of aerosol extinction coefficient $\left(\alpha_{\mathrm{a}}\right)$ and volume depolarization ratio $\left(\delta_{\mathrm{v}}\right)$ were obtained by the lidar during the clear and haze period, respectively. The time-height contour plots of $\alpha_{a}$ and $\delta_{v}$, as well as columnar total, fine and coarse mode AODs at $500 \mathrm{~nm}$ obtained from the sun photometer, are shown in Figure 4. As seen in Figure 4a, columnar AOD at $500 \mathrm{~nm}\left(\tau_{\mathrm{a} 500}\right)$ was $0.41 \pm 0.04$ during the clear period. Coarse mode aerosols $\left(\tau_{\mathrm{a} 500 \mathrm{c}}=0.20 \pm 0.02\right)$ shared a proportion almost equivalent to that of fine mode $\left(\tau_{\mathrm{a} 500 \mathrm{f}}=0.20 \pm 0.04\right)$. During the haze period, $\tau_{\mathrm{a} 500}$ tripled to $1.32 \pm 0.31$, whereas coarse mode aerosol-loading $\left(\tau_{\mathrm{a} 500 \mathrm{c}}=0.11 \pm 0.03\right)$ was interestingly smaller than that during the clear period. That is, fine mode AOD increased by as large as 1.0 on average, suggesting a massive load of submicron particles in the columnar atmosphere. Lidar observations showed consistently high $\alpha_{\mathrm{a}}$ values $\left(0.3-3.0 \mathrm{~km}^{-1}\right)$ below $1.2 \mathrm{~km}$ on these polluted days. Conversely, $\alpha_{\mathrm{a}}$ was no more than $0.3 \mathrm{~km}^{-1}$ throughout the clear period. The convective boundary layer heights were only several hundred meters during the haze period, while aerosol-rich altitudes frequently extended to $>1 \mathrm{~km}$ in the presence of the residual layers. In the free troposphere, elevated aerosol layers (EALs), which can be identified by stronger extinction and different scenarios of depolarization 
compared to the background atmosphere, were visible in the lidar image (Figure $4 \mathrm{~b}, \mathrm{c}$ ). Our lidar captured 9 EALs for the entire period. The EALs had extinction maximums of $0.08-0.43 \mathrm{~km}^{-1}$ and could extend up to an altitude of $4.0 \mathrm{~km}$. Several clouds caused quick attenuation of laser energy, and thereby, no reliable retrievals were available inside and above them.

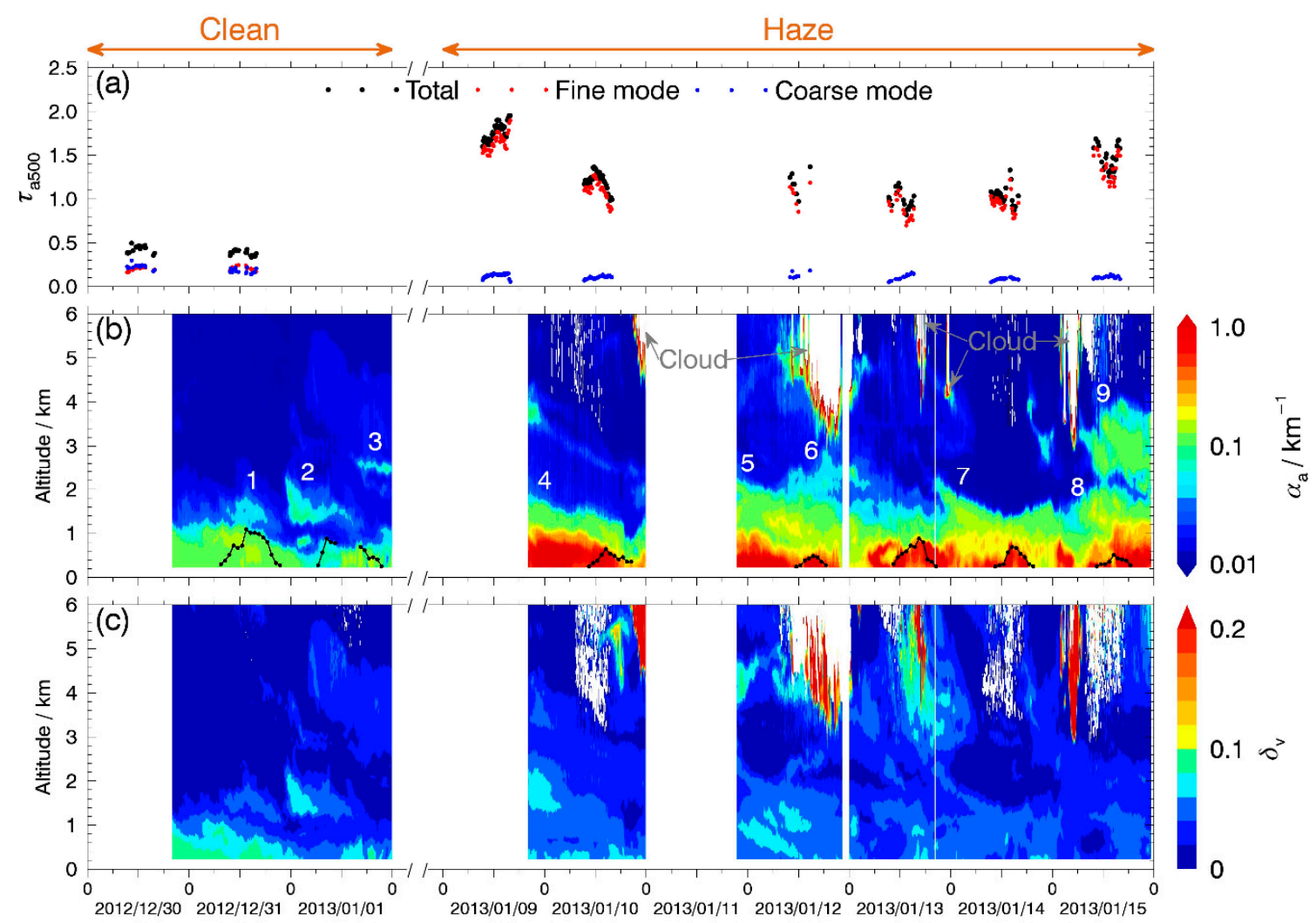

Figure 4. (a) Time series of sun photometer columnar total (black dots), fine (red dots) and coarse mode AOD (blue dots) at $500 \mathrm{~nm}$. Time-height plot of $(\mathbf{b})$ the aerosol extinction coefficient $\left(\alpha_{\mathrm{a}}\right)$ and $(\mathbf{c})$ volume depolarization ratio $\left(\delta_{\mathrm{v}}\right)$ at $532 \mathrm{~nm}$ from lidar measurements during the observation period. In panel (b), the 9 elevated aerosol layers are indexed with numbers above them, and several clouds are indicated. The convective boundary layer heights are retrieved with the variance method [24] using lidar signals and plotted in panel (b) as the black curve with dots.

To further validate lidar aerosol retrievals, we compared lidar-derived $\tau_{\mathrm{a}}$ with coincident sun photometer measurements. Figure 5 a gives the time series of lidar-derived and sun-photometer-measured AOD $\left(\tau_{\mathrm{a}}\right)$ at $532 \mathrm{~nm}$ for the entire period. Lidar $\tau_{\mathrm{a}}$ were obtained by integrating $\alpha_{\mathrm{a}}$ profiles from the ground up to $12 \mathrm{~km}$ when possible. Within the lidar blind area (below $0.2 \mathrm{~km}$ ), no height variation of $\alpha_{\mathrm{a}}$ was assumed. Above $12 \mathrm{~km}$, the amount of aerosol-loading was negligible. Sun photometer $\tau_{\mathrm{a}}$ were interpolated to the lidar wavelength $(532 \mathrm{~nm})$ with the Ångström relationship [68], and the Ångström exponent was computed from linear regression of $\ln \tau_{\mathrm{a}}$ versus $\ln \lambda$ at 440,500, 675, and $870 \mathrm{~nm}$. As seen in Figure 5a, lidar-derived $\tau_{\mathrm{a}}$ closely followed the fluctuations of sun photometer measurements, but with higher availability and finer temporal resolution. For the entire period, there are 124 pairs of concurrent lidar and sun photometer $\tau_{\mathrm{a}}$. Linear regression analysis showed the coefficient of determination $\left(R^{2}\right)$ and root-mean-square-error (RMSE) were 0.84 and 0.10 (Figure $5 \mathrm{~b}$ ), respectively, indicating good agreement between the two datasets. Figure $5 \mathrm{a}$ also suggested notable temporal variations in $\tau_{\mathrm{a}}$ during the haze period. For example, lidar-derived (sun-photometer-measured) $\tau_{\mathrm{a}}$ fell from 1.20 (1.26) at $1200 \mathrm{LT}$ to $0.86(0.91)$ at $1530 \mathrm{LT}$ on 10 January 2013. Lidar $\tau_{\mathrm{a}}$ continued to decrease to $1945 \mathrm{LT}$ when it was only 0.35 . Reversely, lidar-derived (sun-photometer-measured) $\tau_{\mathrm{a}}$ had a drastic increase from $0.93(0.90)$ at 1201 LT to $1.16(1.28)$ at 1446 LT on 12 January. The 
variability may imply the complex processes involving such as dispersion, transport, and sedimentation of aerosol particles [69].
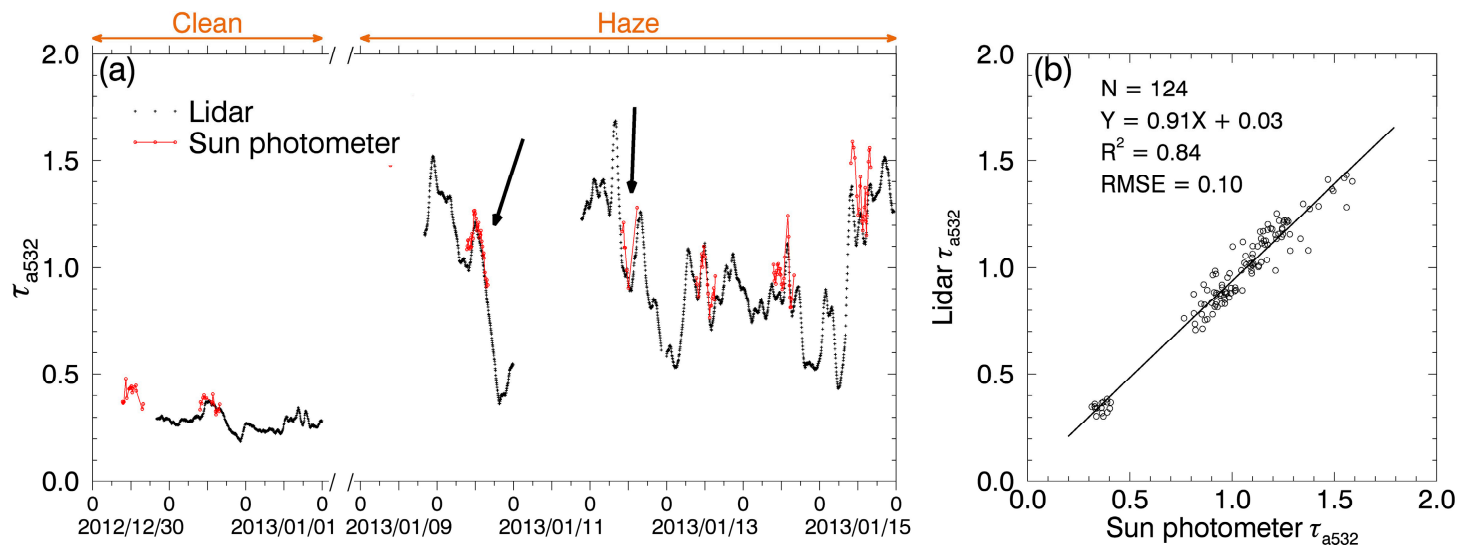

Figure 5. (a) Time series of lidar-derived and sun-photometer-measured aerosol optical depth (AOD) ( $\tau_{\mathrm{a}}$ ) at $532 \mathrm{~nm}$ for the entire period. The two black arrows in panel (a) indicate two examples of notable temporal variations of aerosol-loading during the haze period. (b) Scatterplot of concurrent lidar and sun photometer $\tau_{\mathrm{a}}$ measurements. Results from linear regression of them are annotated at the upper-left corner of panel (b) and indicate good agreement between the two datasets.

Figure 6 presents the time series of the fine mode fraction (FMF) from sun photometer measurements and the integrated particle depolarization ratio $\left(\delta_{\mathrm{a}_{-} \mathrm{ci}}\right)$ inferred from the lidar during the observation period. $\delta_{\text {a_ci }}$ is calculated as the backscatter-weighted average of $\delta_{a}$ across the atmospheric column following Vaughan and Powell [70] and Noh et al. [71]. It thus has the same implication as $\delta_{\mathrm{a}}$ but for columnar aerosols. During the clear period, FMF ranged from 0.40 to 0.61 , indicating the coexistence of coarse and fine mode particles. Meanwhile, $\delta_{\text {a_ci }}$ hovered between $0.07-0.10$. These depolarization values were higher than those for urban/industrial aerosols $(<0.06)$ in Southeast Asia [51] but smaller than those for pure dust (0.28-0.34) detected over Asian dust source regions [49]. Wuhan is susceptible to irregular-shaped, large dust aerosols transported from the Taklamakan and Gobi deserts, especially in spring and winter [72]. The intense construction of subways may also produce some soil dust in the urban area and suburbs of Wuhan. Therefore, the scenario during the clear period was attributed to a mixture of dust and urban/industrial particles. Unlike aerosols characterized under clear weather, haze particles were rather spherical. $\delta_{\text {a_ci }}$ was $0.05 \pm 0.02$ on average, and values lower than 0.03 were detected on the morning of 13 January and in the daytime of 14 and 15 January. Consistently high FMF values $(0.91 \pm 0.03)$ implied the predominance of submicron particles. Qin et al. [73] found FMF values of $0.78 \pm 0.21$ and $0.88 \pm 0.09$ on polluted days from 2013 to 2016 in Beijing and Xuzhou, respectively. Our results were comparable to the latter but obviously larger than the former. Lower FMF values (0.68-0.80) in Beijing were also reported by Bi et al. [74] in January 2013 when haze weather prevailed. On the other hand, the coarse mode fraction (CMF) was only $0.09 \pm 0.03$. The small values of $\delta_{\text {a_ci }}$ and CMF implied the weak influence of large dust particles during the haze period. Generally, the discernible features of Wuhan haze particles revealed their anthropogenic nature.

We examined the vertical extent of aerosols by averaging the $\alpha_{a}$ profiles during the clear and haze period, respectively. The results are shown in Figure 7a. The average $\alpha_{a}$ $\left(\alpha_{\mathrm{a}}^{\text {clear }}(\mathrm{z})\right)$ under the clear weather decreased gradually from $0.14 \mathrm{~km}^{-1}$ near the ground to $0.08 \mathrm{~km}^{-1}$ at the altitude of $1.0 \mathrm{~km}$. The elevated aerosol layers (see Figure $4 \mathrm{~b}$ ) produced two weak maximums in the mean profile at $\sim 1.4$ and $\sim 2.5 \mathrm{~km}$, respectively. Aerosol content was sparse above $3 \mathrm{~km}$. Yet a different vertical stratification $\left(\alpha_{a}^{\text {haze }}(z)\right)$ was observed during the haze period when aerosol-loading exhibited a sharp decrease with increasing altitude in the lowermost troposphere. $\alpha_{\mathrm{a}}$ reached $0.92 \pm 0.36 \mathrm{~km}^{-1}$ at the minimum lidardetectable altitude, while it diminished rapidly to $0.04 \pm 0.03 \mathrm{~km}^{-1}$ at $2 \mathrm{~km}$. This form 
of vertical distribution suggests the substantial production of aerosols of the local scale. These locally-produced aerosols dwelled abundantly in the lowermost troposphere, i.e., the atmospheric boundary layer (ABL), leading to serious impairment of air quality. Figure $7 \mathrm{~b}$ showed the ratio profile $\left(\alpha_{\mathrm{a}}^{\text {haze }}(\mathrm{z}) / \alpha_{\mathrm{a}}^{\text {clear }}(\mathrm{z})\right)$ of average $\alpha_{\mathrm{a}}$ during the haze to the clear period. The ratio profile indicates how strong aerosol concentration increases/decreases at different altitudes under haze weather. As seen from Figure $7 \mathrm{~b}$, the $\alpha_{\mathrm{a}}$ ratio peaked near the ground and ranged from 3.4-6.5 below $1.2 \mathrm{~km}$, indicating an apparent increase of aerosols in the ABL under haze weather. Note that $\alpha_{a}$ ratio was always $>1.0$ (1.11.7 at $2-6 \mathrm{~km}$ ) in the free troposphere. Higher aerosol-loading in the free troposphere reiterated the presence of aerosol transport during the haze period. Moreover, it is known that aerosol vertical distribution is a critical parameter for accurate calculations of earth radiative budget (e.g., [75]). Radiative transfer models assume vertical homogeneity of aerosols [20], which differs profoundly from the distribution observed during the haze period. Such observations are expected to help constrain uncertainties in the assessment of haze radiative forcing.

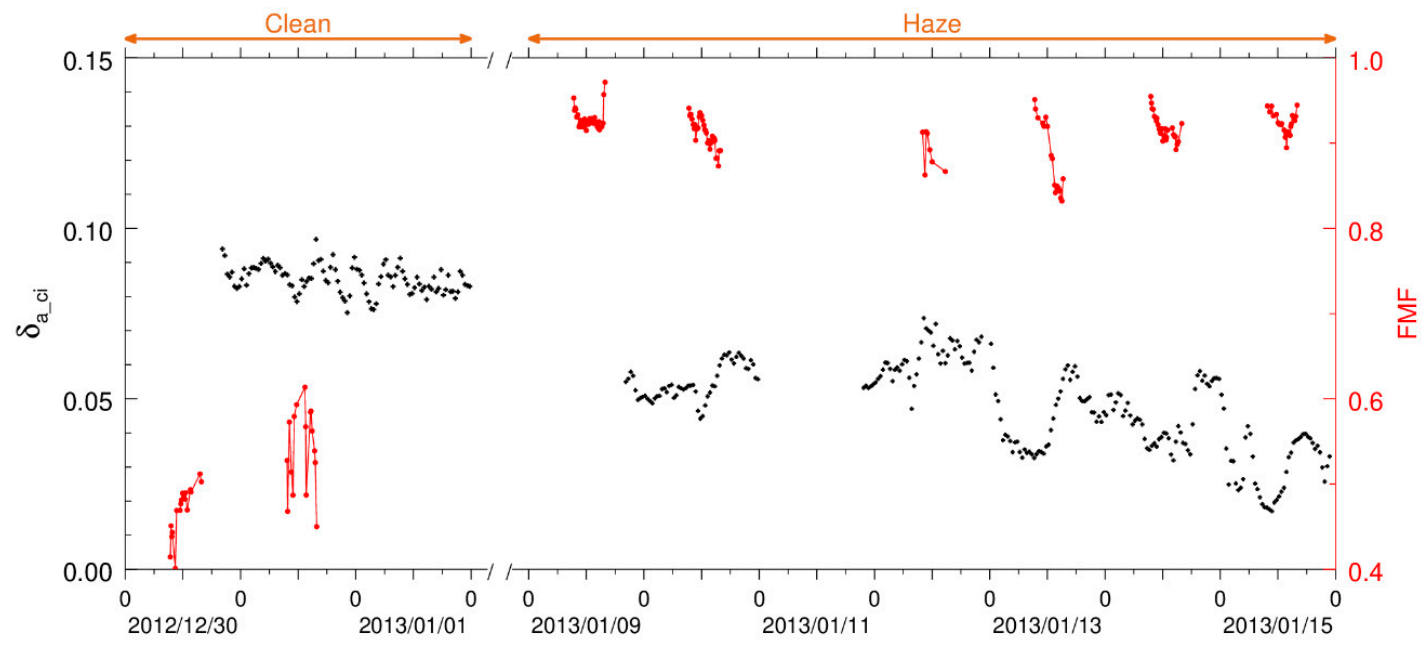

Figure 6. Time series of the fine mode fraction (FMF) from sun photometer measurements and the integrated particle depolarization ratio $\left(\delta_{\mathrm{a} \_\mathrm{c}}\right)$ inferred from the lidar during the entire period. Aerosols were featured by weak depolarization and the predominance of fine mode particles during the haze period.
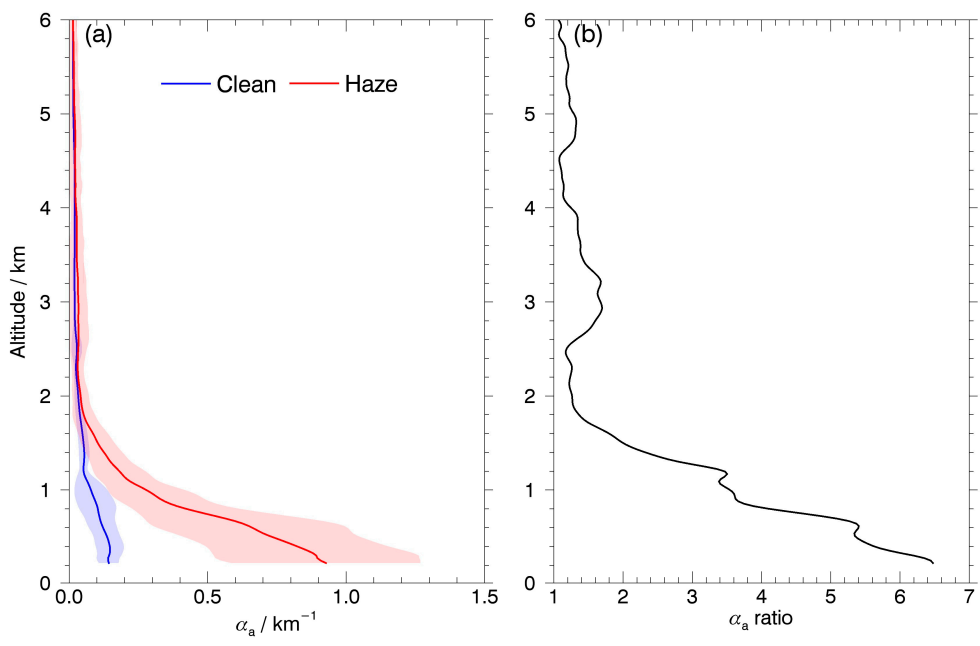

Figure 7. (a) Average $\alpha_{a}$ profiles during the clear (blue) and haze (red) periods, respectively. The shaded areas indicate the standard deviations. (b) The ratio profile of average $\alpha_{a}$ during the haze to the clear period. 
In a word, Wuhan aerosols were featured by weak depolarization, the predominance of fine mode particles, and a sharp decrease of the concentration with height during the haze episode. All these properties linked this haze episode intimately with local emissions from anthropogenic activities.

\subsection{Evolution of Aerosol Vertical Distribution with the ABL Development}

How aerosol vertical distribution evolves with the development of the ABL is a key question in understanding aerosol-ABL interactions [20]. Figure 8 presents the sequence of average hourly profiles of $\alpha_{\mathrm{a}}$ and $\delta_{\mathrm{a}}$ below $2.0 \mathrm{~km}$ from 0800 through $2000 \mathrm{LT}$ on 31 December 2012. Temperature, relative humidity, and wind profiles from same-day soundings at 0800 LT and 2000 LT, respectively, are also plotted. The weather was clear, with the visibility being $12.9 \mathrm{~km}$. Both the morning and evening soundings showed wind speed was up to $10 \mathrm{~m} \cdot \mathrm{s}^{-1}$ below $2 \mathrm{~km}$ except for the ground, indicating favorable conditions for the horizontal diffusion of boundary layer aerosols. In the morning hours, a residual layer from the previous day was discerned with $\alpha_{\mathrm{a}}$ maximum $\left(\sim 0.26 \mathrm{~km}^{-1}\right)$ located at $0.8-0.9 \mathrm{~km}$. Beneath the residual layer, the convective boundary layer (CBL) grew above $0.2 \mathrm{~km}$ at $0800 \mathrm{LT}$ and developed gradually afterward. Meanwhile, local aerosol emissions mixed into the convectively growing boundary layer, and $\alpha_{\mathrm{a}}$ at the altitude of $0.2 \mathrm{~km}$ increased slightly by $\sim 0.08 \mathrm{~km}^{-1}$ from $0800 \mathrm{LT}$ to $1300 \mathrm{LT}$ (Figure $8 \mathrm{c}-\mathrm{g}$. The CBL height rose to $1.09 \mathrm{~km}$ during 1300-1400 LT. At this time, convective mixing drove the particles originally contained in the residual layer to mix down to the lower CBL (Figure 8h), which is a process called fumigation [13]. Despite the fumigation process, $\alpha_{a}$ near the ground decreased by $0.05 \mathrm{~km}^{-1}$ compared to the previous hour under the effect of convective dilution. High CBL heights around $1 \mathrm{~km}$ lasted until 1700 LT, facilitating the dispersion of aerosol particles in the low-level troposphere. Consequently, $\alpha_{\mathrm{a}}$ below $1 \mathrm{~km}$ showed a steady decrease during 1600-2000 LT (Figure 8k-n under well-ventilated meteorology, i.e., favorable conditions for the horizontal and vertical diffusion of boundary layer aerosols. Moreover, no apparent residual layer was formed at night.

As illustrated in Figure 9, a different evolution of the ABL structure and aerosol vertical distribution was observed on 10 January 2013, which was a hazy day. The visibility was $<4 \mathrm{~km}$, and the $\mathrm{PM}_{2.5}$ mass concentration was up to $310 \mu \mathrm{g} \cdot \mathrm{m}^{-3}$. A strong surfacebased inversion was present, with the temperature difference $(\Delta \mathrm{T})$ being $5.5{ }^{\circ} \mathrm{C}$ in the morning. Weak winds (1-4 m.s $\left.{ }^{-1}\right)$ were observed in the lowermost atmosphere. As seen from Figure $9 \mathrm{c}-\mathrm{e}$, the morning residual layer extended to the altitude of $1.0 \mathrm{~km}$ with $\alpha_{\mathrm{a}}$ $>0.6 \mathrm{~km}^{-1}$ throughout the layer. The CBL did not reach the minimum lidar-detectable altitude $(0.2 \mathrm{~km})$ until $1000 \mathrm{LT}$ and exhibited a slow growth afterward. Under the stagnant meteorological conditions, anthropogenic pollutants accumulated rapidly below $0.5 \mathrm{~km}$ in the morning hours. For instance, $\alpha_{\mathrm{a}}$ at $0.2 \mathrm{~km}$ increased dramatically from 0.68 to $1.31 \mathrm{~km}^{-1}$ during 0800-1200 LT (Figure 9c-f. Later, the fumigation process triggered an additional enhancement of aerosol concentration at $0.3-0.4 \mathrm{~km}$ during $1200-1400 \mathrm{LT}$ (Figure $9 \mathrm{~g}, \mathrm{~h}$. The CBL height reached its maximum between 1400 and 1500 LT, and wind speed below $2 \mathrm{~km}$ increased to $\sim 6 \mathrm{~m} \cdot \mathrm{s}^{-1}$ as measured by the evening sounding, suggesting aerosol diffusion conditions were moderately improved in the afternoon. Accordingly, boundary layer $\alpha_{\mathrm{a}}$ decreased gradually during 1500-2000 LT (Figure 9j-n. However, the improved ventilation seemed far from sufficient to wipe out the haze. Although no clouds were detected in the daytime, surface direct solar radiation was only 37\% of that on 31 December 2012 (see Table 2). The maximum CBL height was only $\sim 0.64 \mathrm{~km}$, compared to the climatological average of $0.86 \mathrm{~km}$ in the winter of Wuhan [24]. Hence, when surface sensible heat flux diminished, and the CBL decayed after sunset ( $1800 \mathrm{LT}), \alpha_{\mathrm{a}}$ remained as high as $0.7 \mathrm{~km}^{-1}$ near the ground. 


\section{2/12/31, clean weather}

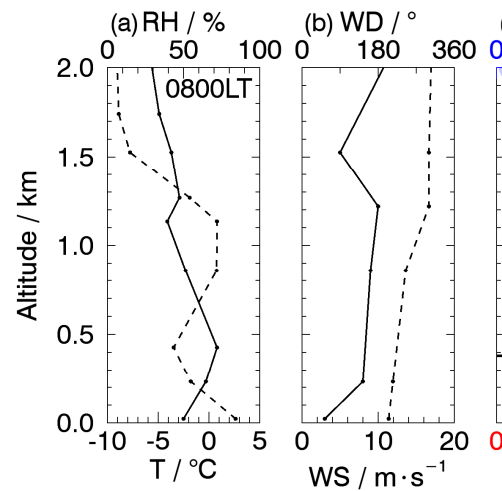

$\begin{array}{llllllllll}\text { (c) } & \delta_{\mathrm{a}} & & \text { (d) } & \delta_{\mathrm{a}} & & \text { (e) } & \delta_{\mathrm{a}} & \\ 0^{0} & 0.1 & 0.2 & 0^{0} & 0.1 & 0.2 & 0^{0.1} & 0.2\end{array}$

(f) $\delta_{\mathrm{a}}$

$0.2 \begin{array}{llll}(\mathrm{g}) & \delta_{\mathrm{a}} & & \\ 0.1 & 0.2 & 0\end{array}$

(h) $\delta_{\mathrm{a}}$
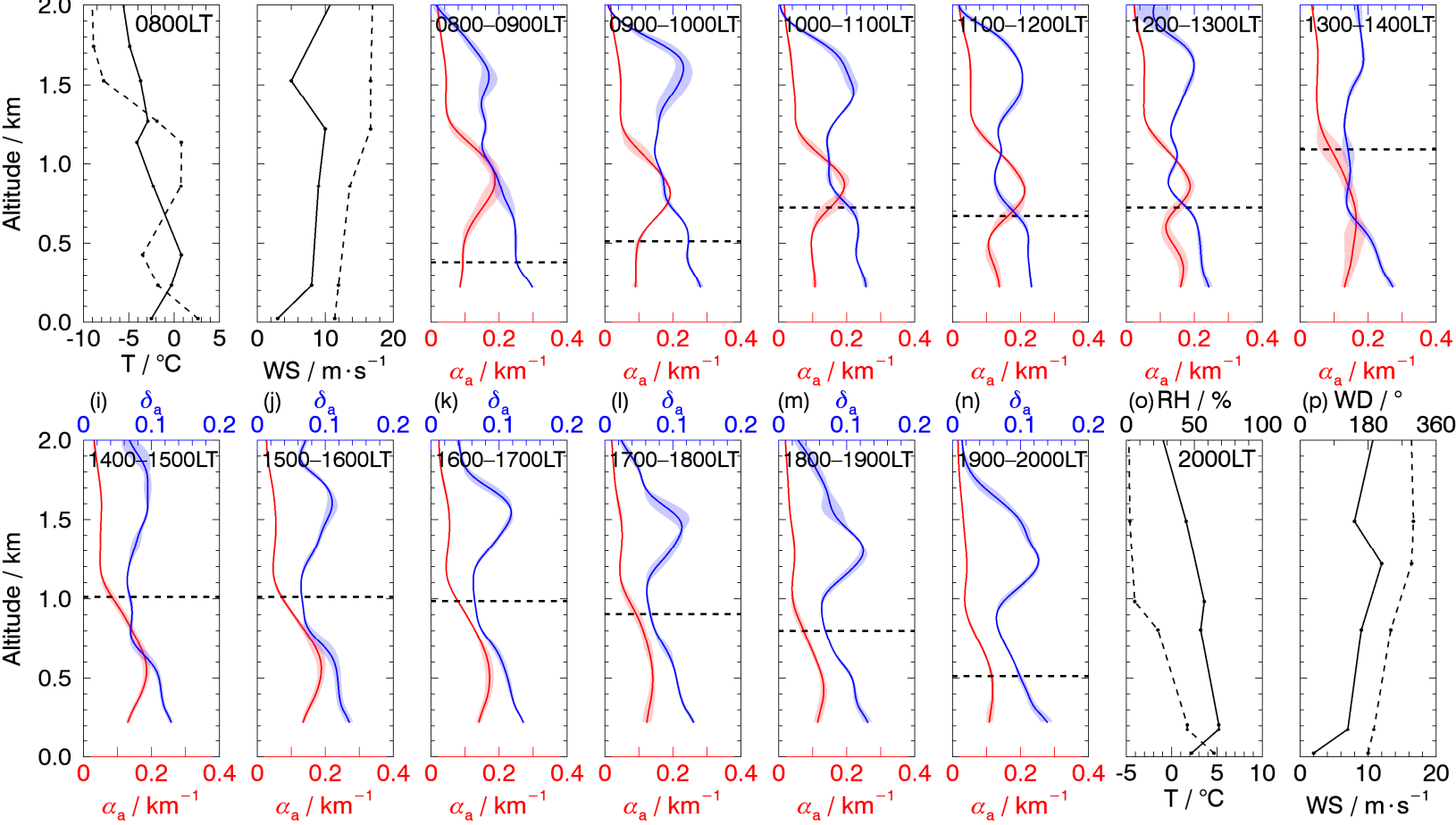

(p) $\mathrm{WD} /{ }^{\circ}$
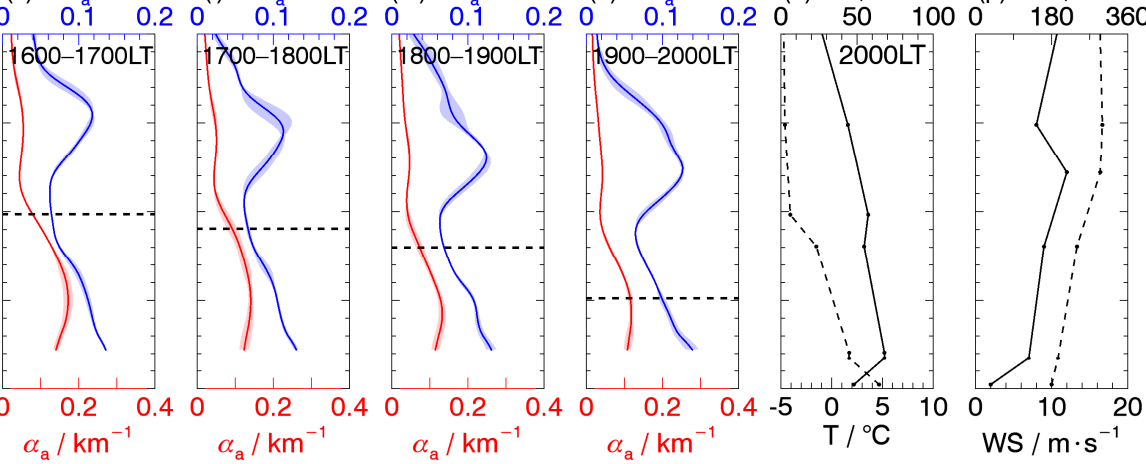

Figure 8. Profiles of (a,o) temperature (solid black line, bottom axis) and relative humidity (black dashed line, top axis), and ( $\mathbf{b}, \mathbf{p})$ wind speed (solid black line, bottom axis) and wind direction (black dashed line, top axis) from the radiosonde measurements at (a,b) 0800 LT and (o,p) 2000 LT, respectively, on 31 December 2012, which was a clear day. Hourly average profiles of $\alpha_{a}$ (red lines, bottom axis) and $\delta_{a}$ (blue lines, top axis) from 0800-2000 LT on the same day are plotted in panels $(\mathbf{c}-\mathbf{n})$ with the convective boundary layer heights being marked as the horizontal dashed lines. The red and blue shades in panels ( $\mathbf{c}-\mathbf{n})$ represent the standard deviations of $\alpha_{a}$ and $\delta_{a}$, respectively.

Table 2. Statistics of boundary-layer meteorological conditions and aerosol vertical extent during the observation period.

\begin{tabular}{|c|c|c|c|c|c|c|c|c|c|}
\hline \multirow{2}{*}{ Date } & \multirow{2}{*}{$\begin{array}{c}0.2 \mathrm{~km} \alpha_{\mathrm{a}} \\
\left(\mathrm{km}^{-1}\right)\end{array}$} & \multicolumn{2}{|c|}{$\Delta \mathrm{T}^{\mathrm{a}}\left({ }^{\circ} \mathrm{C}\right)$} & \multicolumn{2}{|c|}{$\mathrm{WS}^{\mathrm{b}}\left(\mathrm{m} \cdot \mathrm{s}^{-1}\right)$} & \multirow{2}{*}{$\tau_{R L}$} & \multirow{2}{*}{$\mathrm{T}_{\mathrm{CBL}}{ }^{\mathrm{c}}$} & \multirow{2}{*}{$\begin{array}{c}\text { SDSR }^{d} \\
\left(\mathbf{W h} \cdot \mathrm{m}^{-2}\right)\end{array}$} & \multirow{2}{*}{$\begin{array}{c}\mathrm{CBLH}_{\max } \\
(\mathbf{k m})\end{array}$} \\
\hline & & $\begin{array}{c}0800 \\
\text { LT }\end{array}$ & $\begin{array}{c}2000 \\
\text { LT }\end{array}$ & $\begin{array}{c}0800 \\
\text { LT }\end{array}$ & 2000 LT & & & & \\
\hline \multicolumn{10}{|l|}{ Clear } \\
\hline 31 December 2012 & $0.14 \pm 0.03$ & 3.3 & 3.0 & 8.2 & 9.0 & $0.13 \pm 0.01$ & $0800 \mathrm{LT}$ & 2525 & 1.09 \\
\hline 1 January 2013 & $0.12 \pm 0.05$ & 5.7 & 3.6 & 6.1 & 6.0 & $0.05 \pm 0.01$ & $0800 \mathrm{LT}$ & 3167 & 0.88 \\
\hline \multicolumn{10}{|l|}{ Haze } \\
\hline 10 January 2013 & $0.84 \pm 0.25$ & 5.5 & 4.2 & 2.5 & 5.4 & $0.56 \pm 0.02$ & $1000 \mathrm{LT}$ & 944 & 0.64 \\
\hline 12 January 2013 & $1.14 \pm 0.47$ & 5.9 & 2.2 & 3.6 & 3.0 & $0.38 \pm 0.04$ & $1100 \mathrm{LT}$ & 550 & 0.48 \\
\hline 13 January 2013 & $0.73 \pm 0.30$ & 7.1 & 5.2 & 2.8 & 3.3 & $0.41 \pm 0.05$ & $1000 \mathrm{LT}$ & 1225 & 0.88 \\
\hline 14 January 2013 & $0.70 \pm 0.26$ & 8.1 & 4.6 & 3.8 & 7.1 & $0.34 \pm 0.03$ & $1000 \mathrm{LT}$ & 1169 & 0.7 \\
\hline 15 January 2013 & $0.89 \pm 0.36$ & 4.4 & 3.2 & 3.2 & 2.5 & $0.29 \pm 0.04$ & $1000 \mathrm{LT}$ & 778 & 0.51 \\
\hline
\end{tabular}

${ }^{a}$ temperature difference of the inversions. All the inversions occurring on the days listed in the table are surface-based inversions. $b$ average wind speed below $2 \mathrm{~km} .{ }^{c}$ time when the CBL first grew to $0.2 \mathrm{~km}$. ${ }^{\mathrm{d}}$ SDSR $=$ surface direct solar radiation in Wuhan collected from the World Radiation Data Centre (WRDC). Note that there existed thick clouds on 12 and 15 January $2013 .{ }^{\text {e }} \mathrm{CBLH}_{\mathrm{max}}=\mathrm{maximum}$ CBL height. 


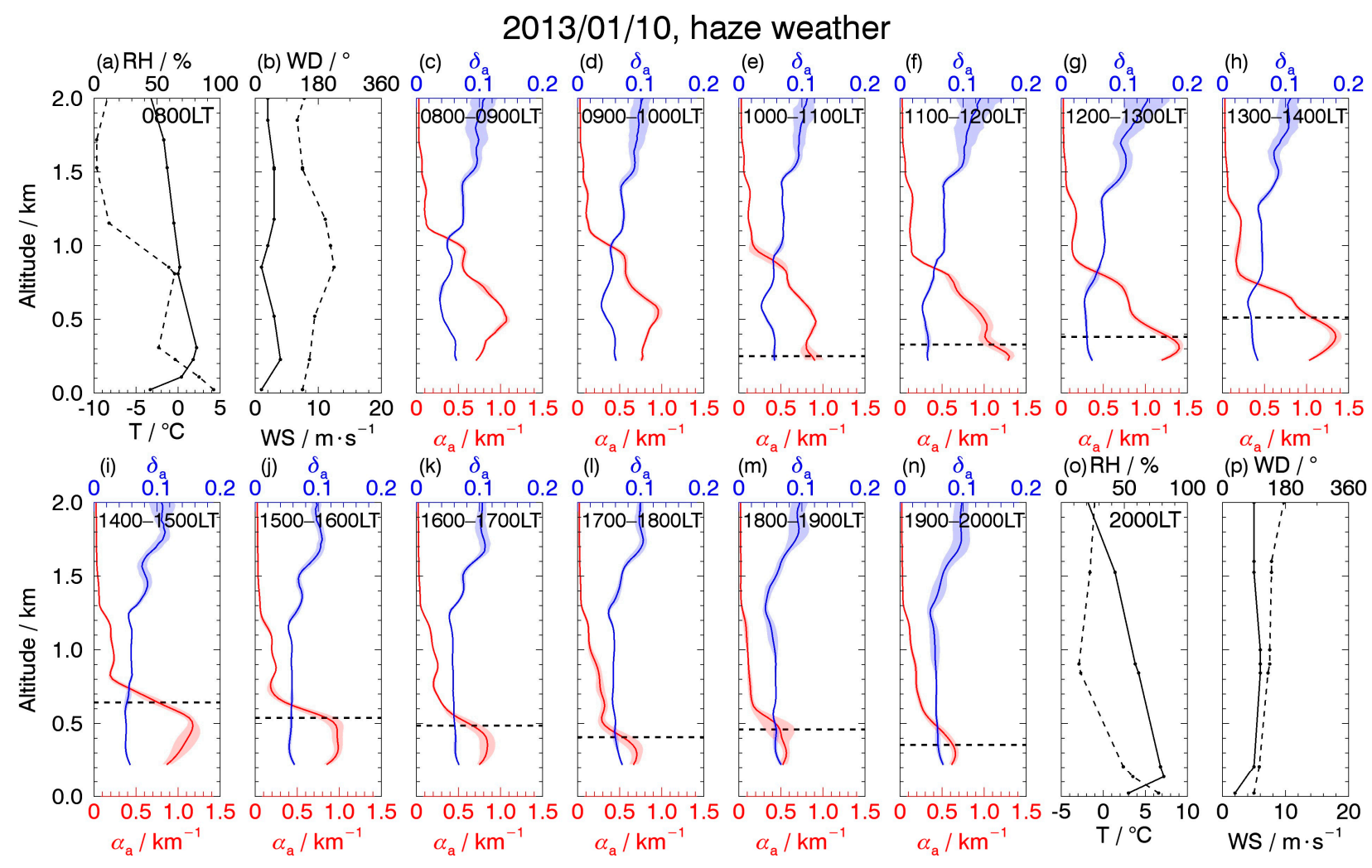

Figure 9. Same as Figure 8 except for 10 January 2013. The weather was hazy, and the evolution of the atmospheric boundary layer (ABL) structure and aerosol vertical distribution was different from that on 31 December 2012.

Figure 10 depicts aerosol evolution in the ABL on 13 January, which was much like that on 10 January. Boundary-layer meteorological conditions remained unfavorable for the diffusion of air pollutants. A strong surface-based inversion $\left(\Delta \mathrm{T}=7.1^{\circ} \mathrm{C}\right)$, weak winds $\left(0-3 \mathrm{~m} \cdot \mathrm{s}^{-1}\right)$, and an aerosol-rich residual layer $\left(\alpha_{\mathrm{a}}\right.$ maximum $\left.>0.8 \mathrm{~km}^{-1}\right)$ still characterized the low-level troposphere in the morning. Similarly, a late growth (from 1000-1100 LT) of the CBL was observed. During 0800-1100 LT, large quantities of particles were confined near the ground. Below the notable residual layer, $\alpha_{a}$ showed a rapid decrease with height (Figure 10c-e. Then, the structure collapsed when abundant particles in the residual layer were fumigated into the growing boundary layer at noon (Figure 10g). The residual layer vanished while $\alpha_{a}$ peaked around $0.5 \mathrm{~km}$. The CBL continued to develop in the afternoon, and both $\alpha_{\mathrm{a}}$ and $\delta_{\mathrm{a}}$ tended to be vertically homogeneous in the CBL (Figure 10h-k. The maximum CBL height was $\sim 0.88 \mathrm{~km}$, but the wind speed was no more than $4 \mathrm{~m} \cdot \mathrm{s}^{-1}$ below $2 \mathrm{~km}$ from the evening radiosonde measurements. Like the situation on 10 January, high $\alpha_{\mathrm{a}}$ $\left(0.5-0.7 \mathrm{~km}^{-1}\right)$ persisted near the ground due to deficient ventilation in the afternoon hours. What was worse, a residual layer began to form after sunset. $\alpha_{\text {a }}$ peaked at $0.6-0.7 \mathrm{~km}$, slightly lower than the maximum CBL height in the afternoon, and its maximum was up to $\sim 1.4 \mathrm{~km}^{-1}$ in the newly formed residual layer. Hazy weather was sustained into the next day. 


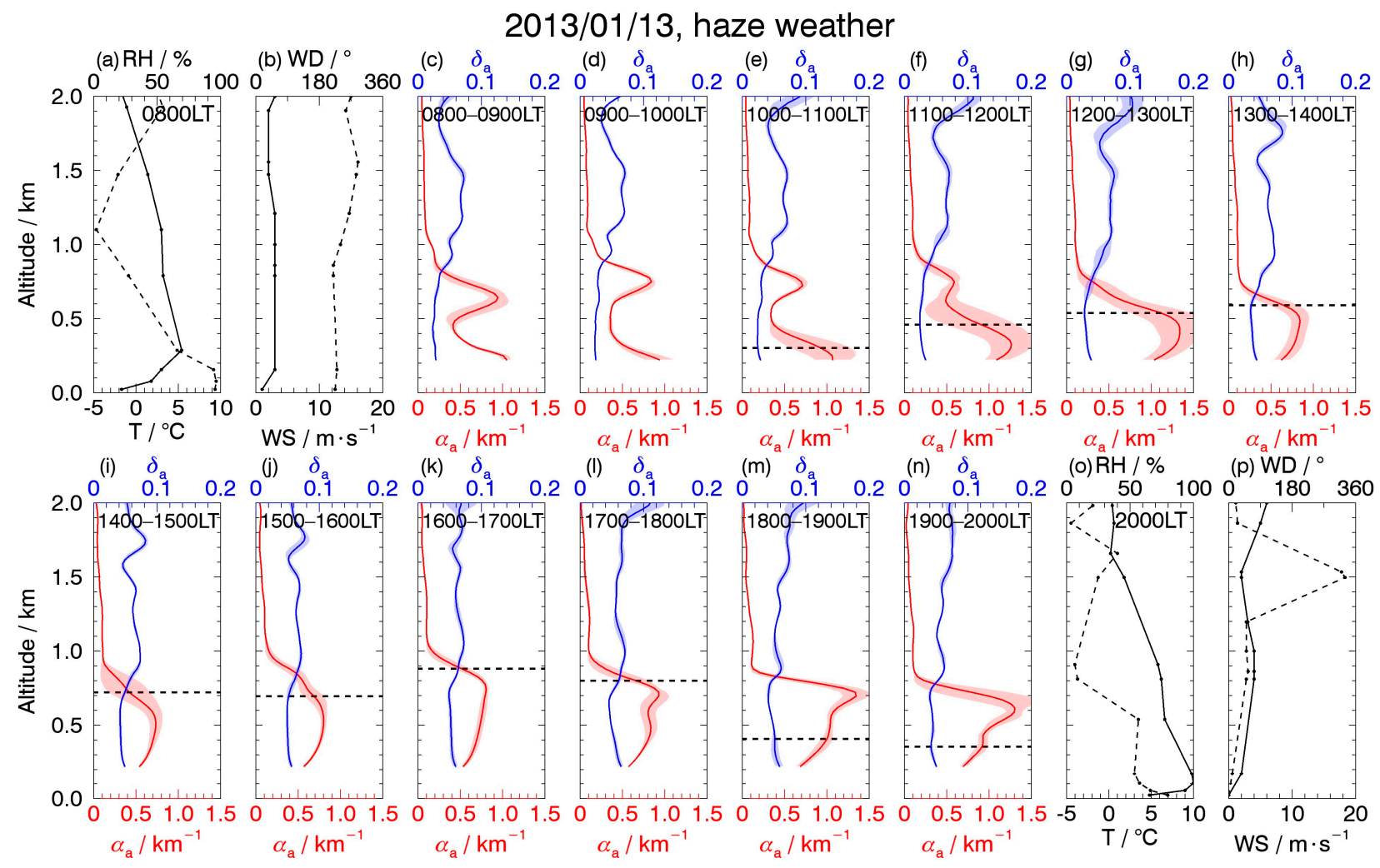

Figure 10. Same as Figure 8 except for 13 January 2013, which was also a hazy day. Aerosol evolution in the ABL on this day was much like that on 10 January except for the formation of a pronounced residual layer in the afternoon.

\subsection{Non-Negligible Influence of the EALs during the Haze Period}

The elevated aerosol layers (EALs) in the free troposphere are subject to regional/longrange transport. On the lidar image, the EALs are readily identified by stronger extinction and different scenarios of depolarization compared to the background atmosphere. A total of nine EALs were captured during the entire period. Two of them (i.e., the EALs indexed with 2 and 7, see Figure $4 \mathrm{~b}$ ) are selected as examples to illustrate the impact of aerosol transport. Our analysis shows the two EALs are representative in terms of aerosol properties, vertical motions, and transport patterns. Figure 11a,b presents the temporal evolution of the layer altitudes of the two EALs. Here, the EAL altitude is defined as the altitude where aerosol extinction maximizes throughout the layer at a given time, following Bitar, Duck, Kristiansen, Stohl and Beauchamp [44]. The EAL in the first example was initially found at 2300 LT on 31 December 2012. It subsided from an altitude of 1.93 to $1.32 \mathrm{~km}$ in only $3 \mathrm{~h}$ and then experienced a slow ascent and descent. The EAL finally settled down to $<1.2 \mathrm{~km}$ at 1800 LT on 1 January 2013 and was not recognizable afterward. The EAL was injected into the ABL, as seen from the time-height plot of $\alpha_{a}$ (see Figure $4 b$ ). The EAL resulted probably from the long-range transport of dust. The corresponding airflow originated from near the source regions of Asian dust, with a trajectory length being $3385 \mathrm{~km}$. Moreover, $\delta_{\mathrm{a}}$ at the layer altitudes was $0.11 \pm 0.01$, and coarse mode AOD at $500 \mathrm{~nm}$ reached $0.18 \pm 0.03$, indicating the presence of large, irregular-shaped dust particles. In the second example, the EAL was characterized by a steady descent from $2.04 \mathrm{~km}$ at $2000 \mathrm{LT}$ on 13 January to $1.17 \mathrm{~km}$ at $0600 \mathrm{LT}$ on 14 January. Meanwhile, $\alpha_{\mathrm{a}}$ at the altitude of $1.0 \mathrm{~km}$ rose continuously from 0.11 to $0.32 \mathrm{~km}^{-1}$, probably due to the injection of the aerosol plume. $\delta_{\mathrm{a}}$ at the layer altitudes was only $0.05 \pm 0.01$, and backward trajectory analysis showed the origin of the related airflow was located in the Sichuan Basin, China. 

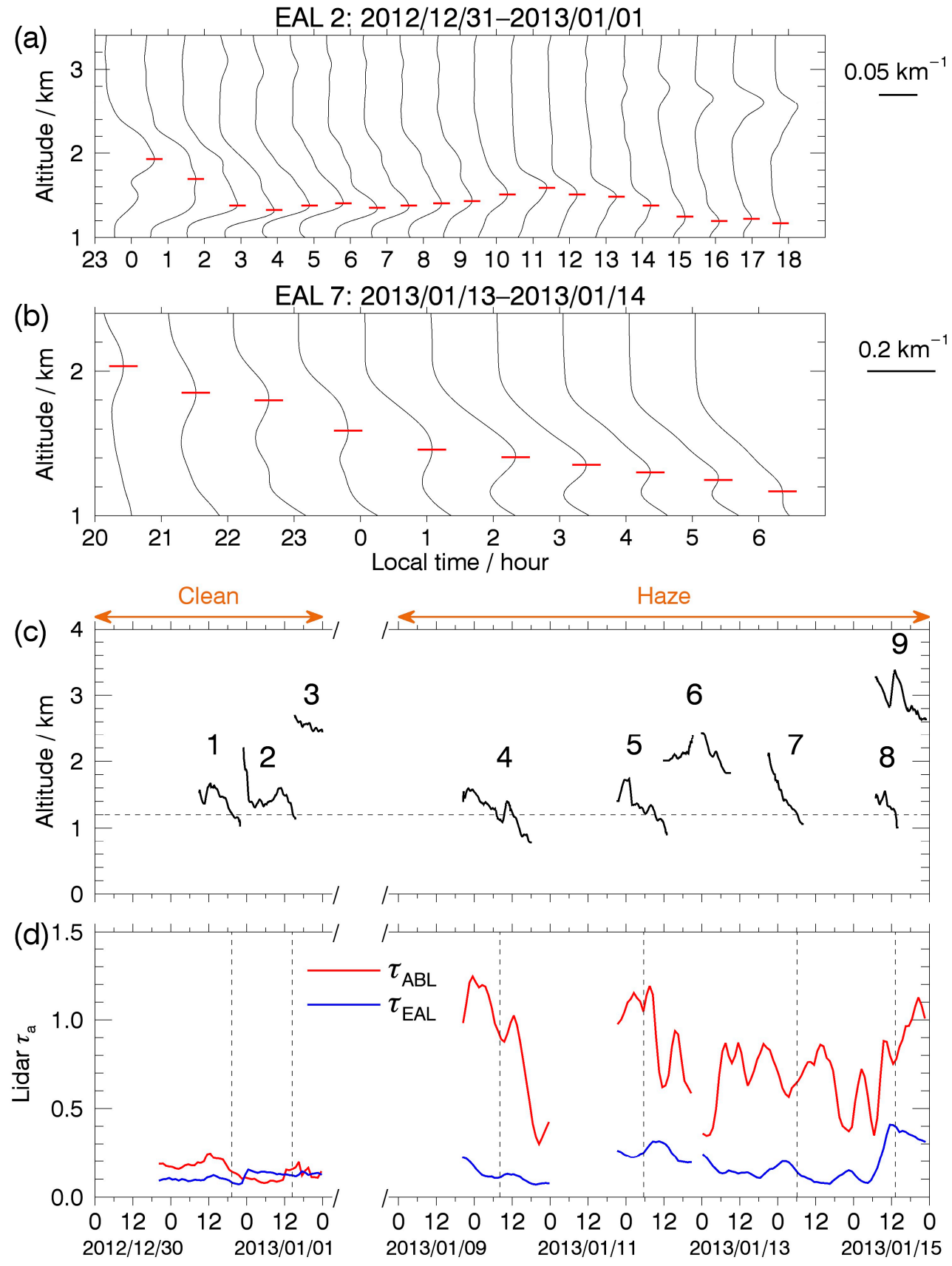

Figure 11. Time-height evolution of the elevated aerosol layers (EALs). The sequence of hourly

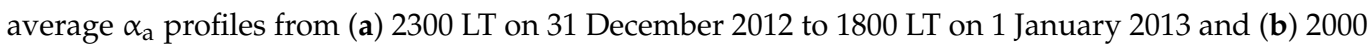
LT on 13 January 2013 to 0600 LT on 14 January 2013. The red short horizontal lines in panels $(\mathbf{a}, \mathbf{b})$ denote the EAL altitudes. Both EALs exhibited subsidence and were injected into the ABL. The time variations of (c) the layer altitudes for each EAL and (d) $\tau_{\mathrm{ABL}}$ and $\tau_{\mathrm{EAL}}$ are summarized. The horizontal dash line in panel (c) indicates the altitude of $1.2 \mathrm{~km}$. The vertical dashed lines in panel (d) indicate the time when any of the EALs descended to $<1.2 \mathrm{~km}$.

We summarized the vertical motions of the nine EALs in Figure 11c. All the EALs generally moved downward; upward motions were only occasionally spotted. Consequently, the average subsidence velocities for the EALs ranged from 8.9 to $94.8 \mathrm{~m} \cdot \mathrm{h}^{-1}$. Specifically, most of the EALs ( 6 out of 9 ) descended to an altitude of $<1.2 \mathrm{~km}$ and then mixed with local aerosols in the ABL, including the residual layer. That is, transported particles in these EALs caused exacerbations of the pollution level. 
To quantitatively evaluate the contribution of the EALs to the haze event, we separated lidar-derived AOD into optical depth roughly from the ABL $\left(\tau_{\mathrm{ABL}}\right)$ and elevated aerosol layers $\left(\tau_{\mathrm{EAL}}\right)$. Boundary layer aerosols extended frequently to an altitude of $\sim 1.2 \mathrm{~km}$, which was slightly higher than the maximum CBL height $(1.09 \mathrm{~km})$ during the entire period. Hence, $\tau_{\mathrm{ABL}}$ and $\tau_{\mathrm{EAL}}$ were obtained by integrating the extinction profiles from the ground to $1.2 \mathrm{~km}$ and from 1.2 to $6 \mathrm{~km}$, respectively. The background optical depth of free tropospheric aerosols, $\sim 0.03$ during the observation period, was subtracted in the calculation of $\tau_{E A L}$. Figure $11 \mathrm{~d}$ shows the time variations of $\tau_{A B L}$ and $\tau_{E A L}$ during the entire period. For the six EALs that eventually mixed with boundary layer aerosols, an increase in $\tau_{\mathrm{ABL}}$ was observed after each of them descended to $<1.2 \mathrm{~km}$, except for the one observed on 31 December 2012, i.e., the EAL indexed with 1 . The increase in $\tau_{\mathrm{ABL}}$ lasted for 3-9 $\mathrm{h}$ with the overall rise being $0.04-0.35$, providing quantitative evidence that regional/long-range transport of particles contributed to the aggravation of the pollution level. As for the exceptional EAL, both $\tau_{\mathrm{ABL}}$ and $\tau_{\mathrm{EAL}}$ decreased after the EAL descended to $<1.2 \mathrm{~km}$, which was possibly associated with well-ventilated conditions (see Figure 8 ). During the haze period, we estimated that the contribution of the EALs was $19 \%$ in terms of optical depth. On the other hand, the EALs had a higher contribution (46\%) during the clear period, owing to a far lower level of boundary layer aerosols (Figure 11d). Our results argue that regional/long-range transport played a non-negligible role in the evolution processes of the intense haze episode.

\subsection{Haze over Central and Eastern China in January 2013}

A variety of places in central and eastern China experienced a severe, long-lasting pollution episode in January 2013, yielding a large-scale weather phenomenon [5,76,77]. The large-scale haze episode regarding its spatial extent and temporal variation is outlined in Figure 12a, which presents the time series of daily weather (clear, haze/fog, or

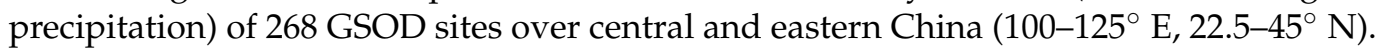
The time window is set from 30 December 2012 to 20 January 2013 for consistency. As revealed by previous studies and Section 3.3 of this study, the ventilation coefficient $\left(\mathrm{V}_{\mathrm{c}}\right)$, which indicates the ability of the ABL to diffuse pollutants in both the horizontal and vertical directions $[63,64]$, is a significant parameter in determining local pollution potential. Climatology studies show $V_{c}$ ranges between 1000 and 10,000 $\mathrm{m}^{2} \cdot \mathrm{s}^{-1}$ (e.g., [78]), while it can be lower than $1000 \mathrm{~m}^{2} \cdot \mathrm{s}^{-1}$ on polluted days and higher than $2000 \mathrm{~m}^{2} \cdot \mathrm{s}^{-1}$ in clear weather $[63,79]$. To examine the applicability of the concept in the large-scale haze episode, we demonstrate the spatial distribution of $\mathrm{V}_{\mathrm{c}}$ over central and eastern China in Figure $12 \mathrm{~b}$. A sequence of six periods was selected within the time window. As shown in Figure 12a, clear weather prevailed from 30 December 2012 to 3 January 2013. Meanwhile, $V_{c}$ values were well above $2000 \mathrm{~m}^{2} \cdot \mathrm{s}^{-1}$ (Figure 12b1) over central and eastern China except for the westernmost part of the studied region, suggesting overall desirable conditions for the diffusion of aerosol particles. On 4 January 2013, haze appeared over small patches of the North China Plain and Yangtze River Delta, where considerable amounts of atmospheric pollutants are emitted owing to high population density and frequent industrial activities [80]. The large quantities of pollutants accumulated under much weaker ventilation (Figure 12b2), leading to the buildup of haze in these places. Subsequently, the majority of central and eastern China was dominated by unfavorable ventilation conditions (Figure 12b3), and continuous expansion of haze coverage was seen from 5 to 9 January when the number of polluted sites increased rapidly from 26 to 81 . From 10 to 15 January, $\mathrm{V}_{\mathrm{c}}$ was $<1000 \mathrm{~m}^{2} \cdot \mathrm{s}^{-1}$ over the studied region (Figure $12 \mathrm{~b} 4$ ), indicating persistently stable meteorology, and the pollution level found its maximum in terms of visibility and spatial extent. Eastern China (roughly $111-123^{\circ} \mathrm{E}$ and $28-40^{\circ} \mathrm{N}$ ), along with the Sichuan Basin, was shrouded by severe air pollution, and MODIS AOD values exceeded 1.0 [76] in these areas. The visibility over the severely polluted region was improved in the next three days when the ventilation was slightly better over most of Eastern China. Large-scale precipitation during 19-20 January finally scavenged the widespread haze plume, as seen 
in the visibility map (Figure 12a). Within the time window, nevertheless, haze weather was rare over the westernmost $\left(100-105^{\circ} \mathrm{E}\right)$ and northernmost $\left(40-45^{\circ} \mathrm{N}\right)$ parts of the studied region, even when unfavorable ventilation conditions were registered. This may be attributed to fewer aerosol emissions [80].

(a)

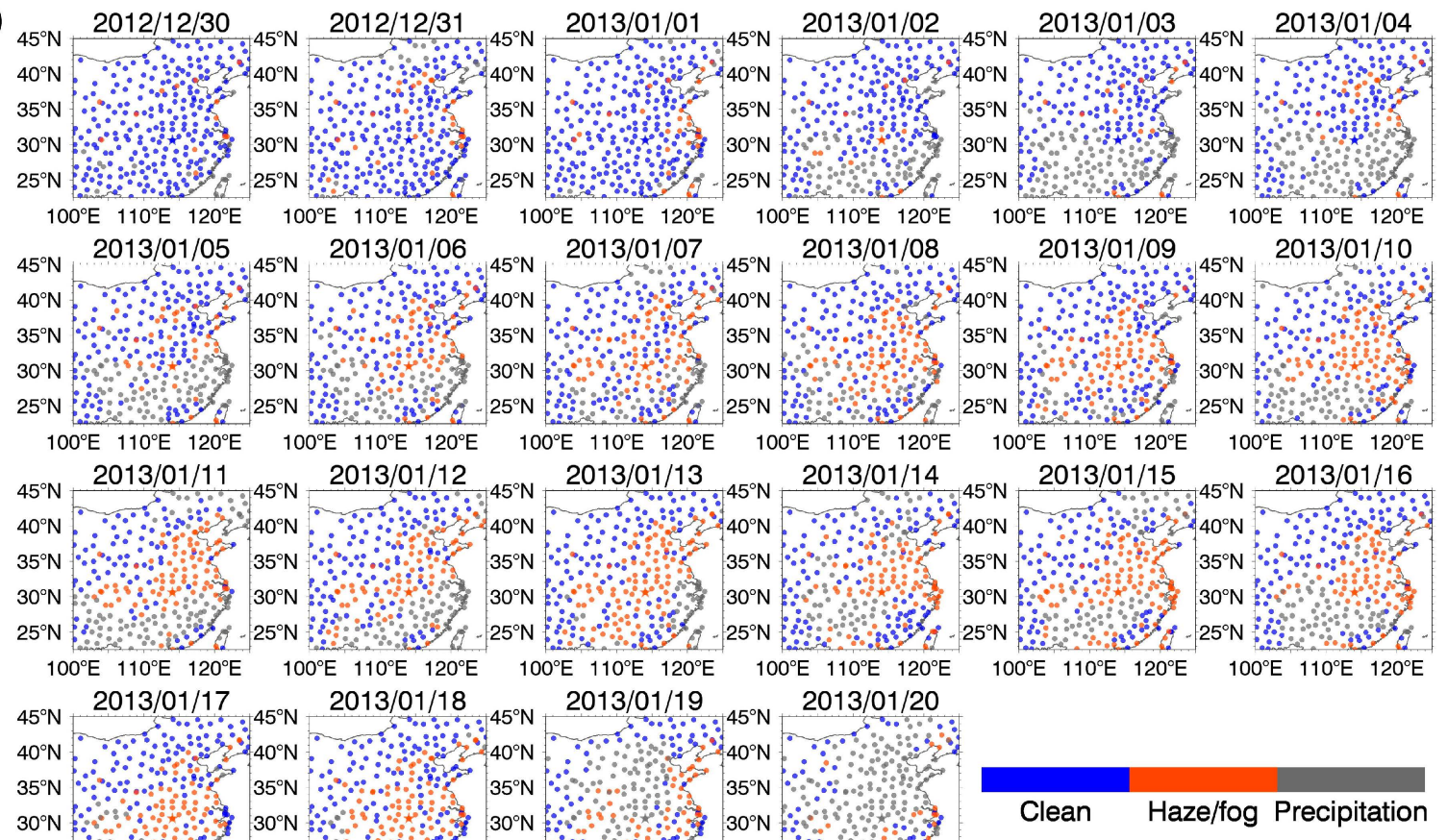

(b) ${ }_{45^{\circ}}$ (b1) $2012 / 12 / 29-2012 / 12 / 30$ (b2) $2013 / 01 / 03-2013 / 01 / 04$

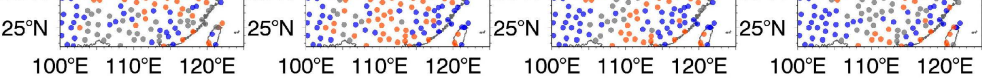
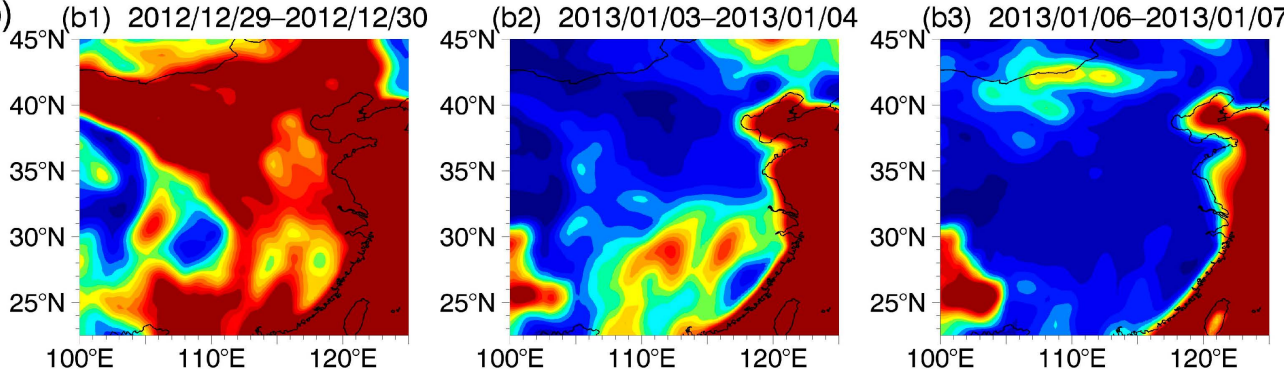

(b4) $2013 / 01 / 12-2013 / 01 / 13$
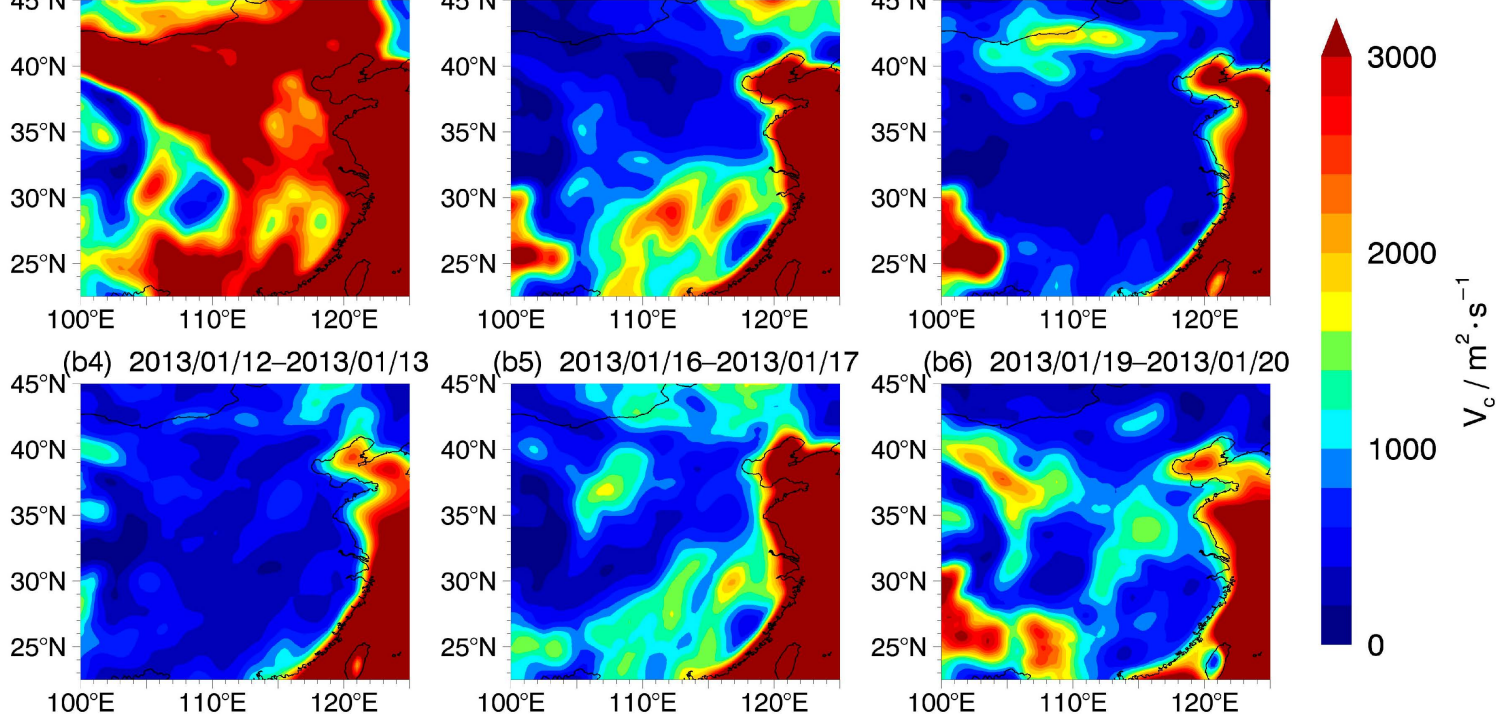

Figure 12. (a) Daily weather conditions of 268 Global Surface Summary of the Day (GSOD) sites over central and eastern China from 30 December 2012 to 20 January 2013. The blue, orange and gray dots denote the location of the sites with clear, haze/fog or precipitation weather, respectively. $(b)$ The spatial extent of the ventilation coefficient $\left(\mathrm{V}_{\mathrm{c}}\right)$ over central and eastern China for a sequence of 6 periods selected from 30 December 2012 to 20 January 2013.

Figure 13 presents the correlation coefficients between the average daily visibility and $V_{c}$ from 30 December 2012 to 20 January 2013 for the GSOD sites over central and eastern China. Only the sites that have sufficient non-precipitation measurements ( $\geq 15$ days) are 
considered. Some sites where reported visibility is always $30 \mathrm{~km}$ (the measuring range of the sensor) through the period are excluded. For each of the remaining $130 \mathrm{GSOD}$ sites, $\mathrm{V}_{\mathrm{c}}$ from the closest ERA5 grid is used in the computation. Since the horizontal resolution of the ERA5 reanalysis is $\sim 31 \mathrm{~km}$, the distances between the GSOD sites and corresponding ERA5 grids are all less than $20 \mathrm{~km}$, indicating spatially fair conformity between the two datasets. As shown in Figure 13, the correlation coefficients between the visibility and $V_{c}$ were overwhelmingly positive. Moreover, the positive correlation was statistically significant at $95 \%$ confidence level or greater for 94 out of the 130 sites, suggesting haze evolution was closely related to atmospheric diffusion conditions expressed by $\mathrm{V}_{\mathrm{c}}$ in January 2013 over eastern and central China. Interestingly, the strongest correlations were found over Eastern China (including Wuhan as expected), the most polluted region during the period studied. In the westernmost region $\left(100-111^{\circ} \mathrm{E}\right)$ with a lower occurrence of haze, the correlations were comparably weaker. It seemed the impact on air quality of atmospheric diffusion conditions exhibited some degree of spatial diversity, which may require further studies involving more places.

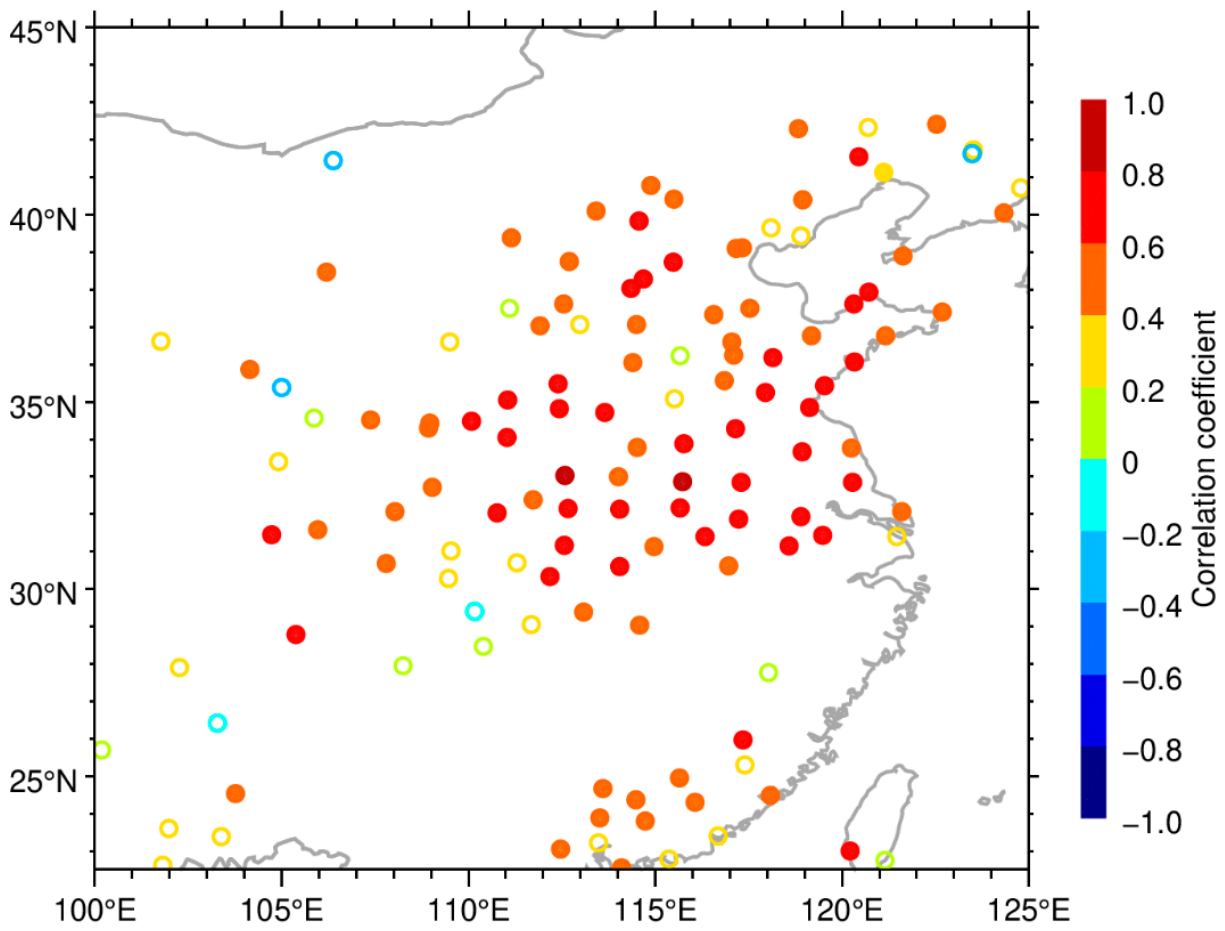

Figure 13. Correlation coefficients between the average daily visibility and $V_{c}$ during 30 December 2012 to 20 January 2013 over central and eastern China. Solid dots indicate values that are statistically significant at $95 \%$ confidence level or greater, while open circles indicate values that are not. Out of the 130 sites, $94(\sim 72 \%)$ have a positive correlation, which is statistically significant at a $95 \%$ confidence level or greater.

\section{Discussion}

In Table 2, we summarize the statistics concerning boundary-layer meteorology and aerosol vertical extent during the observation period. With seven days of statistics, the role of the morning residual layer in aerosol-ABL interactions was discussed. We estimated the aerosol abundance of the morning residual layer with the aerosol optical depth. The upper and lower boundaries of the morning residual layer were determined at approximately 1.2 and $0.4 \mathrm{~km}$, respectively, by inspection of lidar profiles. Accordingly, the morning residual layer AODs $\left(\tau_{\mathrm{RL}}\right)$ were computed by integrating $\alpha_{\mathrm{a}}$ profiles from 0.4 to $1.2 \mathrm{~km}$ and then averaging the integrations during $0700-0900$ LT. Results show $\tau_{R L}$ ranged between $0.29-0.56$ during the haze period (see Table 2). Firstly, the optically thick residual layer could induce 
strong radiative cooling at the surface and/or heating in the upper air (e.g., at $0.5 \mathrm{~km}$ ) and thus hamper the turbulent convection of the low-level troposphere via effective radiative forcing [81]. Hence, the CBL did not grow above $0.2 \mathrm{~km}$ until 1000-1100 LT during the haze period (see Table 2), 2-3 h later than that during the clear period. Anthropogenic emissions therefore accumulated near the ground in the morning hours due to stable meteorological conditions, including a strong surface-based inversion $\left(4.4-8.1{ }^{\circ} \mathrm{C}\right)$, late development of the CBL, and weak wind $\left(2.5-3.8 \mathrm{~m} \cdot \mathrm{s}^{-1}\right)$ in the lowermost troposphere. Second, the optically thick residual layer served as a reservoir of aerosol particles on these polluted days. Around noon, abundant particles in the residual layer were fumigated into the lower CBL, causing further deterioration of air quality (see Figure $9 \mathrm{~g}$, h and Figure $10 \mathrm{~g}$ ). That is, the residual layer influenced air quality indirectly by weakening convective activities in the morning and directly through the fumigation process around noon, suggesting it might be an important element in aerosol-ABL interactions during consecutive days with haze. Like the situation observed in the previous studies $[17,18]$, surface direct solar radiation was greatly reduced under haze weather, contributing to defective development of the CBL. The maximum CBL heights were only $0.48-0.88 \mathrm{~km}$ on these polluted days, and the defectively developed CBL and/or weak wind failed to eliminate haze in the afternoon hours. Consequently, the average daily $\alpha_{\mathrm{a}}$ near the ground exceeded $0.7 \mathrm{~km}^{-1}$ for consecutive days (see Table 2), leading to a serious, long-lasting haze event. In contrast, the temperature inversions were comparably weaker during the clear period. Higher CBL and wind speed provided better ventilation for boundary layer aerosols. Both the direct (fumigation process) and indirect effects (weakening the convective mixing) of the residual layer were observed to be negligible during the clear period, probably due to the much lower concentration of residual aerosols.

To deliver a comprehensive depiction of aerosol transport during the observation period, the origins and transport pathways corresponding to the EALs were discussed by using HYSPLIT and lidar and sun photometer data. The $72 \mathrm{~h}$ backward trajectories related to the 9 EALs during the clear and haze period are mapped in Figure 14a,c, respectively. Statistics of the EALs and corresponding airflows are shown in Table 3. Two distinct pathways, identified by backward trajectory analysis, were confirmed by our lidar and sun photometer measurements. For the three EALs detected during the clear period, all the corresponding airflows originated from the northwest with trajectory lengths exceeding $3000 \mathrm{~km}$. Similar pathways were found for the airflows (the red and orange trajectory in Figure 14c) related to the first two EALs during the haze period. All these source locations were near the Taklamakan and Gobi deserts, two major origins of Asian dust [67]. The HYSPLIT trackings were verified by our lidar and sun photometer observations. In fact, average $\delta_{\mathrm{a}}$ values (see Table 3 ) ranged from 0.08 to 0.11 for these EALs. Coarse mode AOD at $500 \mathrm{~nm}$ reached $0.18 \pm 0.03$ and $0.13 \pm 0.02$ when EAL 2 and EAL 4 \& 5 were registered. All these confirmed the presence of large, non-spherical dust particles. The airflows related to the remaining four EALs during the haze period, however, showed a different yet consistent pattern. The direction of the airflows turned to the west, and the lengths of the trajectories were between 1000-1700 km. Additionally, the source locations (enclosed in Figure 14c) for the four airflows were close in the distance and all situated in the Sichuan Basin, China. The Sichuan Basin, owing to its topographic features and substantial anthropogenic emissions, is one of the most polluted regions in China [80]. Small $\delta_{\mathrm{a}}$ values (0.01-0.05, see Table 3) were found for the plumes transported from the Sichuan Basin. Generally, the pathways for the transport in Wuhan during the haze period were quite different from those in Beijing, where regional transport via the southwest pathway could lead to severe pollution episodes [82], and those in winter of Wuxi from 2013 to 2015 when there were obvious contributions of anthropogenic aerosols from southern regions [83]. The comprehensive depiction (origins, transport pathways, and time-height evolution of the EALs) of aerosol transport can be useful for air quality forecasting and control in Wuhan. 

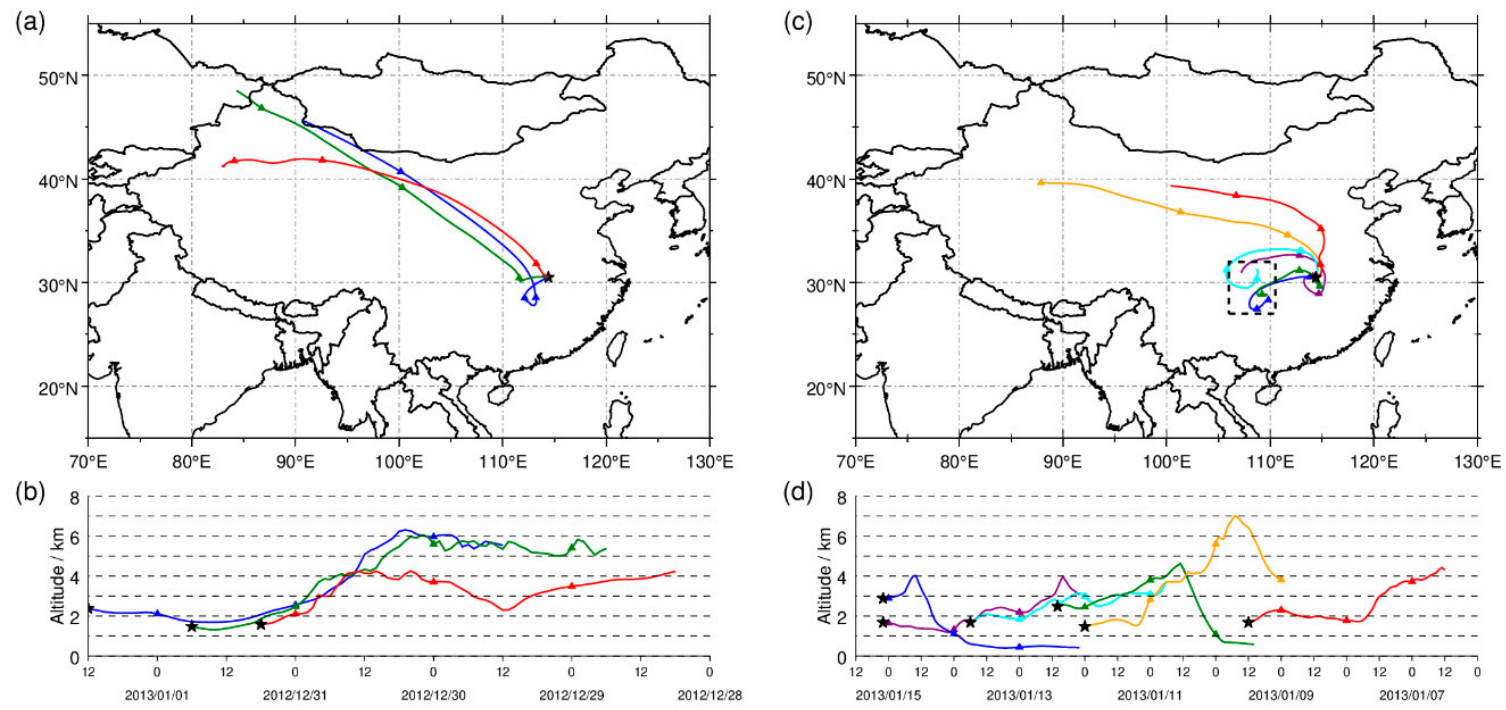

Figure 14. The $72 \mathrm{~h}$ backward trajectories associated with the lidar-detected EALs during the (a,b) clear and (c,d) haze period, respectively. The rectangle in panel (c) enclosed the source locations corresponding to the last 4 EALs during the haze period.

Table 3. Statistics of the EALs and corresponding airflows during the observation period.

\begin{tabular}{ccccc}
\hline \multirow{2}{*}{ Index } & \multicolumn{2}{c}{ Lidar-Detected EAL } & \multicolumn{2}{c}{ HYSPLIT Backward Trajectory } \\
\cline { 2 - 5 } & $\boldsymbol{\alpha}_{\mathbf{a}}$ Maximum $\left(\mathbf{k m}^{-\mathbf{1}}\right)$ & $\boldsymbol{\delta}_{\mathbf{a}} \mathbf{a}$ & Airflow Direction & Trajectory Length (km) \\
\hline Clear & & & & \\
1 & 0.08 & $0.11 \pm 0.01$ & Northwest & 3211 \\
2 & 0.10 & $0.11 \pm 0.01$ & Northwest & 3385 \\
3 & 0.10 & $0.10 \pm 0.02$ & Northwest & 1952 \\
Haze & & & & 2806 \\
4 & 0.32 & $0.09 \pm 0.02$ & Northwest & 1027 \\
5 & 0.41 & $0.08 \pm 0.03$ & Northwest & 1679 \\
6 & 0.16 & $0.02 \pm 0.01$ & West & 1513 \\
8 & 0.29 & $0.05 \pm 0.01$ & West & 1056 \\
9
\end{tabular}

${ }^{a}$ average $\delta_{a}$ at the layer altitudes during the evolution of each EAL.

\section{Conclusions}

In January 2013, widespread, long-lasting haze clouds blanketed central and eastern China, including Wuhan $\left(30.5^{\circ} \mathrm{N}, 114.4^{\circ} \mathrm{E}\right)$, a highly industrialized and densely populated megacity. On the most polluted days, the $\mathrm{PM}_{2.5}$ mass concentration reached $270-310 \mu \mathrm{g} \cdot \mathrm{m}^{-3}$, and the visibility was less than $4 \mathrm{~km}$. The collaborative observations from a polarization lidar and sun photometer, which are scarce in central China, allow us to investigate the process-level evolution of aerosols in both the ABL and elevated layers during the haze period. The main conclusions are drawn as follows:

1. During the haze period, the integrated particle depolarization ratio was $0.05 \pm 0.02$, and the fine mode fraction of AOD reached $0.91 \pm 0.03$. Aerosol extinction peaked near the ground and exhibited a sharp decrease with increasing altitude. These characterizations linked this haze episode intimately with substantial anthropogenic emissions of the local scale;

2. The daytime evolution of aerosol vertical distribution in the ABL showed a distinct pattern on polluted days. Abundant particles accumulated below $0.5 \mathrm{~km}$ in the morning hours due to stable meteorological conditions, including a strong surface- 
based inversion $\left(4.4-8.1{ }^{\circ} \mathrm{C}\right)$, late development (from 1000-1100 LT) of the convective boundary layer, and weak wind $\left(2.5-3.8 \mathrm{~m} \cdot \mathrm{s}^{-1}\right)$ in the lowermost troposphere. In the afternoon, improved ventilation delivered an overall reduction in boundary layer aerosols but was still insufficient to eliminate haze. Particularly, the morning residual layer had an AOD of between 0.29 and 0.56, serving as the reservoir of aerosol particles. The optically thick residual layer influenced air quality indirectly by weakening convective mixing in the morning hours and directly through the fumigation process around noon, suggesting it may be an important element in aerosol-ABL interactions during consecutive days with haze;

3. In January 2013 , the positive correlations between the visibility and ventilation coefficients were statistically significant at a $95 \%$ confidence level for $72 \%$ of the GSOD sites over central and eastern China, linking the large-scale haze episode tightly with poor ventilation. Moreover, the strongest correlations were found over the most polluted area (roughly $111-123^{\circ} \mathrm{E}$ and $28-40^{\circ} \mathrm{N}$, including Wuhan);

4. Most of the lidar-captured elevated aerosol layers (EALs) were observed to subside eventually into the ABL and thereby exacerbate the pollution level. Combined backward trajectory analysis and lidar data revealed the EALs came from the transport of anthropogenic pollutants from the Sichuan Basin, China, and of dust from the Taklamakan and Gobi deserts. We estimated aerosol transport via the two pathways contributed approximately 19\% of columnar AOD during the haze episode. Considering the severity and persistence of this haze episode, we suggested aerosol transport play a non-negligible role in the evolution processes of haze.

Overall, we presented a detailed characterization of aerosol evolution in the timeheight domain during a severe, prolonged haze episode in a megacity. The results benefit the complete understanding of aerosol-ABL interactions under haze weather. Furthermore, the comprehensive depiction of aerosol transport can be useful for air quality forecasting and control in Wuhan.

Author Contributions: Conceptualization, Y.Z. (Yunfei Zhang); methodology, Y.Z. (Yunfei Zhang), Y.Z. (Yunpeng Zhang) and C.Y.; data curation and formal analysis and writing-original draft preparation, Y.Z. (Yunfei Zhang); writing-review and editing, Y.Z. (Yunfei Zhang), Y.Z. (Yunpeng Zhang), C.Y., and F.Y.; funding acquisition: F.Y. All authors have read and agreed to the published version of the manuscript.

Funding: This study was funded by the National Natural Science Foundation of China (Grant number: 41927804). The Meridian Space Weather Monitoring Project (China) provided additional financial support for the lidar maintenance.

Data Availability Statement: The data presented in this study are available on request from the corresponding author.

Acknowledgments: The authors would like to thank the U.S. National Climatic Data Center and World Radiation Data Center for the provision of meteorological measurements. We thank the National Oceanic and Atmospheric Administration's Air Resources Laboratory for the development of the HYSPLIT model and the European Center for Medium-Range Weather Forecasts for ERA5 reanalysis. We gratefully acknowledge Norm T. O'Neill from Université de Sherbrooke, Canada, for providing the spectral deconvolution algorithm code. Data used to generate the results of this paper are available from the authors upon request (E-mail: zhangyunf@whu.edu.cn).

Conflicts of Interest: The authors declare no conflict of interest.

\section{References}

1. Ding, Y.H.; Liu, Y.J. Analysis of long-term variations of fog and haze in China in recent 50 years and their relations with atmospheric humidity. Sci. China-Earth Sci. 2014, 57, 36-46. [CrossRef]

2. Zheng, B.; Tong, D.; Li, M.; Liu, F.; Hong, C.P.; Geng, G.N.; Li, H.Y.; Li, X.; Peng, L.Q.; Qi, J.; et al. Trends in China's anthropogenic emissions since 2010 as the consequence of clean air actions. Atmos. Chem. Phys. 2018, 18, 14095-14111. [CrossRef]

3. Song, C.B.; Wu, L.; Xie, Y.C.; He, J.J.; Chen, X.; Wang, T.; Lin, Y.C.; Jin, T.S.; Wang, A.X.; Liu, Y.; et al. Air pollution in China: Status and spatiotemporal variations. Environ. Pollut. 2017, 227, 334-347. [CrossRef] 
4. Liu, Z.R.; Hu, B.; Ji, D.S.; Cheng, M.T.; Gao, W.K.; Shi, S.Z.; Xie, Y.Z.; Yang, S.H.; Gao, M.; Fu, H.B.; et al. Characteristics of fine particle explosive growth events in Beijing, China: Seasonal variation, chemical evolution pattern and formation mechanism. Sci. Total Environ. 2019, 687, 1073-1086. [CrossRef]

5. Zheng, G.J.; Duan, F.K.; Su, H.; Ma, Y.L.; Cheng, Y.; Zheng, B.; Zhang, Q.; Huang, T.; Kimoto, T.; Chang, D.; et al. Exploring the severe winter haze in Beijing: The impact of synoptic weather, regional transport and heterogeneous reactions. Atmos. Chem. Phys. 2015, 15, 2969-2983. [CrossRef]

6. Wang, Y.S.; Yao, L.; Wang, L.L.; Liu, Z.R.; Ji, D.S.; Tang, G.Q.; Zhang, J.K.; Sun, Y.; Hu, B.; Xin, J.Y. Mechanism for the formation of the January 2013 heavy haze pollution episode over central and eastern China. Sci. China-Earth Sci. 2014, 57, 14-25. [CrossRef]

7. Gao, M.; Carmichael, G.R.; Wang, Y.; Saide, P.E.; Yu, M.; Xin, J.; Liu, Z.; Wang, Z. Modeling study of the 2010 regional haze event in the North China Plain. Atmos. Chem. Phys. 2016, 16, 1673-1691. [CrossRef]

8. An, Z.S.; Huang, R.J.; Zhang, R.Y.; Tie, X.X.; Li, G.H.; Cao, J.J.; Zhou, W.J.; Shi, Z.G.; Han, Y.M.; Gu, Z.L.; et al. Severe haze in northern China: A synergy of anthropogenic emissions and atmospheric processes. Proc. Natl. Acad. Sci. USA 2019, 116, 8657-8666. [CrossRef] [PubMed]

9. Ramanathan, V.; Chung, C.; Kim, D.; Bettge, T.; Buja, L.; Kiehl, J.T.; Washington, W.M.; Fu, Q.; Sikka, D.R.; Wild, M. Atmospheric brown clouds: Impacts on South Asian climate and hydrological cycle. Proc. Natl. Acad. Sci. USA 2005, 102, 5326-5333. [CrossRef] [PubMed]

10. Navarro, J.C.A.; Varma, V.; Riipinen, I.; Seland, O.; Kirkevag, A.; Struthers, H.; Iversen, T.; Hansson, H.C.; Ekman, A.M.L. Amplification of Arctic warming by past air pollution reductions in Europe. Nat. Geosci. 2016, 9, 277-281. [CrossRef]

11. Brunekreef, B.; Holgate, S.T. Air pollution and health. Lancet 2002, 360, 1233-1242. [CrossRef]

12. Pope, C.A., III; Dockery, D.W. Health effects of fine particulate air pollution: Lines that connect. J. Air Waste Manag. Assoc. 2006, 56, 709-742. [CrossRef] [PubMed]

13. Wolf, T.; Esau, I.; Reuder, J. Analysis of the vertical temperature structure in the Bergen valley, Norway, and its connection to pollution episodes. J. Geophys. Res. Atmos. 2014, 119, 10645-10662. [CrossRef]

14. Pal, S.; Lee, T.R.; Phelps, S.; De Wekker, S.F.J. Impact of atmospheric boundary layer depth variability and wind reversal on the diurnal variability of aerosol concentration at a valley site. Sci. Total Environ. 2014, 496, 424-434. [CrossRef]

15. Stull, R.B. An Introduction to Boundary Layer Meteorology; Springer: Berlin/Heidelberg, Germany, 1988; pp. 1-27.

16. Zhang, R.H.; Li, Q.; Zhang, R.N. Meteorological conditions for the persistent severe fog and haze event over eastern China in January 2013. Sci. China-Earth Sci. 2014, 57, 26-35. [CrossRef]

17. Petäjä, T.; Järvi, L.; Kerminen, V.M.; Ding, A.J.; Sun, J.N.; Nie, W.; Kujansuu, J.; Virkkula, A.; Yang, X.; Fu, C.B.; et al. Enhanced air pollution via aerosol-boundary layer feedback in China. Sci. Rep. 2016, 6, 18998. [CrossRef]

18. Quan, J.N.; Gao, Y.; Zhang, Q.; Tie, X.X.; Cao, J.J.; Han, S.Q.; Meng, J.W.; Chen, P.F.; Zhao, D.L. Evolution of planetary boundary layer under different weather conditions, and its impact on aerosol concentrations. Particuology 2013, 11, 34-40. [CrossRef]

19. Huang, X.; Wang, Z.L.; Ding, A.J. Impact of Aerosol-PBL Interaction on Haze Pollution: Multiyear Observational Evidences in North China. Geophys. Res. Lett. 2018, 45, 8596-8603. [CrossRef]

20. Li, Z.Q.; Guo, J.P.; Ding, A.J.; Liao, H.; Liu, J.J.; Sun, Y.L.; Wang, T.J.; Xue, H.W.; Zhang, H.S.; Zhu, B. Aerosol and boundary-layer interactions and impact on air quality. Natl. Sci. Rev. 2017, 4, 810-833. [CrossRef]

21. Su, T.N.; Li, Z.Q.; Li, C.C.; Li, J.; Han, W.C.; Shen, C.Y.; Tan, W.S.; Wei, J.; Guo, J.P. The significant impact of aerosol vertical structure on lower atmosphere stability and its critical role in aerosol-planetary boundary layer (PBL) interactions. Atmos. Chem. Phys. 2020, 20, 3713-3724. [CrossRef]

22. Zhang, Q.; Ma, X.C.; Tie, X.X.; Huang, M.Y.; Zhao, C.S. Vertical distributions of aerosols under different weather conditions: Analysis of in-situ aircraft measurements in Beijing, China. Atmos. Environ. 2009, 43, 5526-5535. [CrossRef]

23. Baars, H.; Ansmann, A.; Engelmann, R.; Althausen, D. Continuous monitoring of the boundary-layer top with lidar. Atmos. Chem. Phys. 2008, 8, 7281-7296. [CrossRef]

24. Kong, W.; Yi, F. Convective boundary layer evolution from lidar backscatter and its relationship with surface aerosol concentration at a location of a central China megacity. J. Geophys. Res. Atmos. 2015, 120, 7928-7940. [CrossRef]

25. Wang, Z.F.; Li, J.; Wang, Z.; Yang, W.Y.; Tang, X.; Ge, B.Z.; Yan, P.Z.; Zhu, L.L.; Chen, X.S.; Chen, H.S.; et al. Modeling study of regional severe hazes over mid-eastern China in January 2013 and its implications on pollution prevention and control. Sci. China-Earth Sci. 2014, 57, 3-13. [CrossRef]

26. Qin, K.; Wu, L.X.; Wong, M.S.; Letu, H.; Hu, M.Y.; Lang, H.M.; Sheng, S.J.; Teng, J.Y.; Xiao, X.; Yuan, L.M. Trans-boundary aerosol transport during a winter haze episode in China revealed by ground-based Lidar and CALIPSO satellite. Atmos. Environ. 2016, 141, 20-29. [CrossRef]

27. Guo, S.; Hu, M.; Zamora, M.L.; Peng, J.F.; Shang, D.J.; Zheng, J.; Du, Z.F.; Wu, Z.; Shao, M.; Zeng, L.M.; et al. Elucidating severe urban haze formation in China. Proc. Natl. Acad. Sci. USA 2014, 111, 17373-17378. [CrossRef] [PubMed]

28. Li, P.F.; Yan, R.C.; Yu, S.C.; Wang, S.; Liu, W.P.; Bao, H.M. Reinstate regional transport of PM2.5 as a major cause of severe haze in Beijing. Proc. Natl. Acad. Sci. USA 2015, 112, E2739-E2740. [CrossRef]

29. Wang, Q.Q.; Sun, Y.L.; Xu, W.Q.; Du, W.; Zhou, L.B.; Tang, G.Q.; Chen, C.; Cheng, X.L.; Zhao, X.J.; Ji, D.S.; et al. Vertically resolved characteristics of air pollution during two severe winter haze episodes in urban Beijing, China. Atmos. Chem. Phys. 2018, 18, 2495-2509. [CrossRef] 
30. Onishi, K.; Kurosaki, Y.; Otani, S.; Yoshida, A.; Sugimoto, N.; Kurozawa, Y. Atmospheric transport route determines components of Asian dust and health effects in Japan. Atmos. Environ. 2012, 49, 94-102. [CrossRef]

31. McKendry, I.; Strawbridge, K.; Karumudi, M.L.; O’Neill, N.; Macdonald, A.M.; Leaitch, R.; Jaffe, D.; Cottle, P.; Sharma, S.; Sheridan, P.; et al. Californian forest fire plumes over Southwestern British Columbia: Lidar, sunphotometry, and mountaintop chemistry observations. Atmos. Chem. Phys. 2011, 11, 465-477. [CrossRef]

32. Ansmann, A.; Tesche, M.; Gross, S.; Freudenthaler, V.; Seifert, P.; Hiebsch, A.; Schmidt, J.; Wandinger, U.; Mattis, I.; Muller, D.; et al. The 16 April 2010 major volcanic ash plume over central Europe: EARLINET lidar and AERONET photometer observations at Leipzig and Munich, Germany. Geophys. Res. Lett. 2010, 37, 5. [CrossRef]

33. Zhang, F.; Wang, Z.W.; Cheng, H.R.; Lv, X.P.; Gong, W.; Wang, X.M.; Zhang, G. Seasonal variations and chemical characteristics of PM2.5 in Wuhan, central China. Sci. Total Environ. 2015, 518, 97-105. [CrossRef] [PubMed]

34. Liu, B.M.; Ma, Y.Y.; Gong, W.; Zhang, M.; Yang, J. Study of continuous air pollution in winter over Wuhan based on ground-based and satellite observations. Atmos. Pollut. Res. 2018, 9, 156-165. [CrossRef]

35. Zhang, Y.P.; Yi, F.; Kong, W.; Yi, Y. Slope characterization in combining analog and photon count data from atmospheric lidar measurements. Appl. Opt. 2014, 53, 7312-7320. [CrossRef] [PubMed]

36. Newsom, R.K.; Turner, D.D.; Mielke, B.; Clayton, M.; Ferrare, R.; Sivaraman, C. Simultaneous analog and photon counting detection for Raman lidar. Appl. Opt. 2009, 48, 3903-3914. [CrossRef] [PubMed]

37. Zhuang, J.; Yi, F. Nabro aerosol evolution observed jointly by lidars at a mid-latitude site and CALIPSO. Atmos. Environ. 2016, 140, 106-116. [CrossRef]

38. Fernald, F.G. Analysis of atmospheric lidar observations: Some comments. Appl. Opt. 1984, 23, 652-653. [CrossRef]

39. Klett, J.D. Stable analytical inversion solution for processing lidar returns. Appl. Opt. 1981, 20, 211-220. [CrossRef]

40. Wang, W.; Gong, W.; Mao, F.Y.; Pan, Z.X.; Liu, B.M. Measurement and Study of Lidar Ratio by Using a Raman Lidar in Central China. Int. J. Environ. Res. Public Health 2016, 13, 13. [CrossRef]

41. Burton, S.P.; Ferrare, R.A.; Vaughan, M.A.; Omar, A.H.; Rogers, R.R.; Hostetler, C.A.; Hair, J.W. Aerosol classification from airborne HSRL and comparisons with the CALIPSO vertical feature mask. Atmos. Meas. Tech. 2013, 6, 1397-1412. [CrossRef]

42. Sasano, Y.; Browell, E.V. Light scattering characteristics of various aerosol types derived from multiple wavelength lidar observations. Appl. Opt. 1989, 28, 1670-1679. [CrossRef] [PubMed]

43. CALIPSO Lidar Level 3 Tropospheric Aerosol Profiles, Cloud Free Data, Standard V4-20;CAL_LID_L3_Tropospheric_APro_CloudFreeStandard-V4-20; NASA/LARC/SD/ASDC: Hampton, VA, USA, 2019.

44. Bitar, L.; Duck, T.J.; Kristiansen, N.I.; Stohl, A.; Beauchamp, S. Lidar observations of Kasatochi volcano aerosols in the troposphere and stratosphere. J. Geophys. Res. Atmos. 2010, 115, 10. [CrossRef]

45. Comerón, A.; Rocadenbosch, F.; López, M.A.; Rodríguez, A.; Muñoz, C.; García-Vizcaíno, D.; Sicard, M. Effects of noise on lidar data inversion with the backward algorithm. Appl. Opt. 2004, 43, 2572-2577. [CrossRef] [PubMed]

46. Freudenthaler, V.; Esselborn, M.; Wiegner, M.; Heese, B.; Tesche, M.; Ansmann, A.; Muller, D.; Althausen, D.; Wirth, M.; Fix, A.; et al. Depolarization ratio profiling at several wavelengths in pure Saharan dust during SAMUM 2006. Tellus Ser. B Chem. Phys. Meteorol. 2009, 61, 165-179. [CrossRef]

47. Sassen, K. Polarization in Lidar. In Lidar: Range-Resolved Optical Remote Sensing of the Atmosphere; Weitkamp, C., Ed.; Springer: New York, NY, USA, 2005; pp. 19-42.

48. Behrendt, A.; Nakamura, T. Calculation of the calibration constant of polarization lidar and its dependency on atmospheric temperature. Opt. Express 2002, 10, 805-817. [CrossRef] [PubMed]

49. Liu, Z.Y.; Fairlie, T.D.; Uno, I.; Huang, J.F.; Wu, D.; Omar, A.; Kar, J.; Vaughan, M.; Rogers, R.; Winker, D.; et al. Transpacific transport and evolution of the optical properties of Asian dust. J. Quant. Spectrosc. Radiat. Transf. 2013, 116, 24-33. [CrossRef]

50. Sakai, T.; Nagai, T.; Zaizen, Y.; Mano, Y. Backscattering linear depolarization ratio measurements of mineral, sea-salt, and ammonium sulfate particles simulated in a laboratory chamber. Appl. Opt. 2010, 49, 4441-4449. [CrossRef]

51. Müller, D.; Ansmann, A.; Mattis, I.; Tesche, M.; Wandinger, U.; Althausen, D.; Pisani, G. Aerosol-type-dependent lidar ratios observed with Raman lidar. J. Geophys. Res. Atmos. 2007, 112. [CrossRef]

52. Dieudonne, E.; Chazette, P.; Marnas, F.; Totems, J.; Shang, X. Raman Lidar Observations of Aerosol Optical Properties in 11 Cities from France to Siberia. Remote Sens. 2017, 9, 978. [CrossRef]

53. Shaw, G.E. Sun Photometry. Bull. Amer. Meteorol. Soc. 1983, 64, 4-10. [CrossRef]

54. Holben, B.N.; Eck, T.F.; Slutsker, I.; Tanre, D.; Buis, J.P.; Setzer, A.; Vermote, E.; Reagan, J.A.; Kaufman, Y.J.; Nakajima, T.; et al. AERONET-A federated instrument network and data archive for aerosol characterization. Remote Sens. Environ. 1998, 66, 1-16. [CrossRef]

55. Eck, T.F.; Holben, B.N.; Reid, J.S.; Dubovik, O.; Smirnov, A.; O’Neill, N.T.; Slutsker, I.; Kinne, S. Wavelength dependence of the optical depth of biomass burning, urban, and desert dust aerosols. J. Geophys. Res. Atmos. 1999, 104, 31333-31349. [CrossRef]

56. Smirnov, A.; Holben, B.N.; Eck, T.F.; Dubovik, O.; Slutsker, I. Cloud-screening and quality control algorithms for the AERONET database. Remote Sens. Environ. 2000, 73, 337-349. [CrossRef]

57. O'Neill, N.T.; Dubovik, O.; Eck, T.F. Modified Ångström exponent for the characterization of submicrometer aerosols. Appl. Opt. 2001, 40, 2368-2375. [CrossRef]

58. O'Neill, N.T.; Eck, T.F.; Smirnov, A.; Holben, B.N.; Thulasiraman, S. Spectral discrimination of coarse and fine mode optical depth. J. Geophys. Res. Atmos. 2003, 108, 15. [CrossRef] 
59. National Centers for Environmental Information. Global Surface Summary of the Day-GSOD. Available online: https://www. ncei.noaa.gov/access/search/dataset-search (accessed on 30 December 2020).

60. Hou, S.Q.; Tong, S.R.; Ge, M.F.; An, J.L. Comparison of atmospheric nitrous acid during severe haze and clean periods in Beijing, China. Atmos. Environ. 2016, 124, 199-206. [CrossRef]

61. Liu, X.G.; Gu, J.W.; Li, Y.P.; Cheng, Y.F.; Qu, Y.; Han, T.T.; Wang, J.L.; Tian, H.Z.; Chen, J.; Zhang, Y.H. Increase of aerosol scattering by hygroscopic growth: Observation, modeling, and implications on visibility. Atmos. Res. 2013, 132, 91-101. [CrossRef]

62. Hersbach, H.; Bell, B.; Berrisford, P.; Hirahara, S.; Horanyi, A.; Munoz-Sabater, J.; Nicolas, J.; Peubey, C.; Radu, R.; Schepers, D.; et al. The ERA5 global reanalysis. Q. J. R. Meteorol. Soc. 2020, 1-51. [CrossRef]

63. Deng, T.; Wu, D.; Deng, X.J.; Tan, H.B.; Li, F.; Liao, B.T. A vertical sounding of severe haze process in Guangzhou area. Sci. China Earth Sci. 2014, 57, 2650-2656. [CrossRef]

64. Holzworth, G.C. Mixing Depths, Wind Speeds and Air Pollution Potential for Selected Locations in the United States. J. Appl. Meteorol. 1967, 6, 1039-1044. [CrossRef]

65. Rigby, M.; Timmis, R.; Toumi, R. Similarities of boundary layer ventilation and particulate matter roses. Atmos. Environ. 2006, 40, 5112-5124. [CrossRef]

66. Stein, A.F.; Draxler, R.R.; Rolph, G.D.; Stunder, B.J.B.; Cohen, M.D.; Ngan, F. NOAA's HYSPLIT Atmospheric Transport and Dispersion Modeling System. Bull. Amer. Meteorol. Soc. 2015, 96, 2059-2077. [CrossRef]

67. Huang, J.; Minnis, P.; Chen, B.; Huang, Z.W.; Liu, Z.Y.; Zhao, Q.Y.; Yi, Y.H.; Ayers, J.K. Long-range transport and vertical structure of Asian dust from CALIPSO and surface measurements during PACDEX. J. Geophys. Res. Atmos. 2008, 113, 13. [CrossRef]

68. Ångström, A. On the Atmospheric Transmission of Sun Radiation and on Dust in the Air. Geogr. Ann. 1929, 11, 156-166. [CrossRef]

69. Friedlander, S.K. Smoke, Dust, and Haze: Fundamentals of Aerosol Dynamics; Oxford University Press: New York, NY, USA, 2000; pp. 59-124.

70. Vaughan, M.A.; Powell, K.A. CALIOP Algorithm Theoretical Basis Document Part. 2: Feature Detection and Layer Properties Algorithms; PC-SCI-202 Part 2; NASA: Washington, DC, USA, 2005; pp. 1-87.

71. Noh, Y.; Müller, D.; Lee, K.; Kim, K.; Lee, K.; Shimizu, A.; Sano, I.; Park, C.B. Depolarization ratios retrieved by AERONET sun-sky radiometer data and comparison to depolarization ratios measured with lidar. Atmos. Chem. Phys. 2017, 17, 6271-6290. [CrossRef]

72. He, Y.; Yi, F. Dust Aerosols Detected Using a Ground-Based Polarization Lidar and CALIPSO over Wuhan $\left(30.5^{\circ} \mathrm{N}, 114.4^{\circ} \mathrm{E}\right)$, China. Adv. Meteorol. 2015, 18. [CrossRef]

73. Qin, K.; Wang, L.Y.; Xu, J.; Letu, H.S.; Zhang, K.F.; Li, D.; Zou, J.H.; Fan, W.Z. Haze Optical Properties from Long-Term Ground-Based Remote Sensing over Beijing and Xuzhou, China. Remote Sens. 2018, 10, 518. [CrossRef]

74. Bi, J.R.; Huang, J.P.; Hu, Z.Y.; Holben, B.N.; Guo, Z.Q. Investigating the aerosol optical and radiative characteristics of heavy haze episodes in Beijing during January of 2013. J. Geophys. Res. Atmos. 2014, 119, 9884-9900. [CrossRef]

75. Haywood, J.M.; Shine, K.P. Multi-spectral calculations of the direct radiative forcing of tropospheric sulphate and soot aerosols using a column model. Q. J. R. Meteorol. Soc. 1997, 123, 1907-1930. [CrossRef]

76. Wang, H.; Tan, S.C.; Wang, Y.; Jiang, C.; Shi, G.Y.; Zhang, M.X.; Che, H.Z. A multisource observation study of the severe prolonged regional haze episode over eastern China in January 2013. Atmos. Environ. 2014, 89, 807-815. [CrossRef]

77. Tao, M.H.; Chen, L.F.; Xiong, X.Z.; Zhang, M.G.; Ma, P.F.; Tao, J.H.; Wang, Z.F. Formation process of the widespread extreme haze pollution over northern China in January 2013: Implications for regional air quality and climate. Atmos. Environ. 2014, 98, 417-425. [CrossRef]

78. Lu, C.; Deng, Q.-H.; Liu, W.-W.; Huang, B.-L.; Shi, L.-Z. Characteristics of ventilation coefficient and its impact on urban air pollution. J. Cent. South. Univ. Technol. 2012, 19, 615-622. [CrossRef]

79. Sun, K.; Liu, H.N.; Ding, A.J.; Wang, X.Y. WRF-Chem Simulation of a Severe Haze Episode in the Yangtze River Delta, China. Aerosol Air Qual. Res. 2016, 16, 1268-1283. [CrossRef]

80. Zhang, X.Y.; Wang, Y.Q.; Niu, T.; Zhang, X.C.; Gong, S.L.; Zhang, Y.M.; Sun, J.Y. Atmospheric aerosol compositions in China: Spatial/temporal variability, chemical signature, regional haze distribution and comparisons with global aerosols. Atmos. Chem. Phys. 2012, 12, 779-799. [CrossRef]

81. Ma, Y.J.; Ye, J.H.; Xin, J.Y.; Zhang, W.Y.; de Arellano, J.V.G.; Wang, S.G.; Zhao, D.D.; Dai, L.D.; Ma, Y.X.; Wu, X.Y.; et al. The Stove, Dome, and Umbrella Effects of Atmospheric Aerosol on the Development of the Planetary Boundary Layer in Hazy Regions. Geophys. Res. Lett. 2020, 47, 10. [CrossRef]

82. Zhang, J.S.; Chen, Z.Y.; Lu, Y.H.; Gui, H.Q.; Liu, J.G.; Liu, W.Q.; Wang, J.; Yu, T.Z.; Cheng, Y.; Chen, Y.; et al. Characteristics of aerosol size distribution and vertical backscattering coefficient profile during 2014 APEC in Beijing. Atmos. Environ. 2017, 148, 30-41. [CrossRef]

83. Fan, W.Z.; Qin, K.; Xu, J.; Yuan, L.M.; Li, D.; Jin, Z.; Zhang, K.F. Aerosol vertical distribution and sources estimation at a site of the Yangtze River Delta region of China. Atmos. Res. 2019, 217, 128-136. [CrossRef] 